This is the author's final, peer-reviewed manuscript as accepted for publication. The publisher-formatted version may be available through the publisher's web site or your institution's library.

\title{
An ionicity rationale to design solid phase metal nitride reactants for solar ammonia production
}

Ronald Michalsky, Peter H. Pfromm

How to cite this manuscript

If you make reference to this version of the manuscript, use the following information:

Michalsky, R., \& Pfromm, P. H. (2012). An ionicity rationale to design solid phase metal nitride reactants for solar ammonia production. Retrieved from http://krex.ksu.edu

\section{Published Version Information}

Citation: Michalsky, R., \& Pfromm, P. H. (2012). An ionicity rationale to design solid phase metal nitride reactants for solar ammonia production. Journal of Physical Chemistry C, 116(44), 23243-23251.

Copyright: @ 2012 American Chemical Society

Digital Object Identifier (DOI): doi:10.1021/jp307382r

Publisher's Link: http://pubs.acs.org/doi/abs/10.1021/jp307382r

This item was retrieved from the K-State Research Exchange (K-REx), the institutional repository of Kansas State University. K-REx is available at http://krex.ksu.edu 


\title{
An ionicity rationale to design solid phase metal nitride reactants for solar ammonia production
}

\author{
Ronald Michalsky ${ }^{1,2, \#}$, Peter H. Pfromm ${ }^{2, *}$ \\ ${ }^{1}$ NSF IGERT associate in biorefining, ${ }^{2}$ Department of Chemical Engineering, 1005 Durland \\ Hall, Kansas State University, Manhattan, Kansas, 66506, United States
}

\begin{abstract}
Ammonia is an important fertilizer component and could be used as a convenient hydrogen carrier. This work studies a solar thermochemical reaction cycle that separates the reductive $\mathrm{N}_{2}$ cleavage from the hydrogenation of nitrogen ions to $\mathrm{NH}_{3}$ without using electricity or fossil fuel. The hydrolysis of binary metal nitrides of magnesium, aluminum, calcium, chromium, manganese, zinc, or molybdenum at $0.1 \mathrm{MPa}$ and $200-1000^{\circ} \mathrm{C}$ recovered up to $100 \mathrm{~mol} \%$ of the lattice nitrogen with up to $69.9 \mathrm{~mol}^{\%}$ as $\mathrm{NH}_{3}$ liberated at rates of up to $1.45 \times 10^{-3} \mathrm{~mol} \mathrm{NH}_{3}(\mathrm{~mol}$ metal) $)^{-1} \mathrm{~s}^{-1}$ for ionic nitrides. These rates and recoveries are encouraging when extrapolated to a full scale process. However, nitrides with lower ionicity are attractive due to simplified reduction conditions to recycle the oxidized reactant after $\mathrm{NH}_{3}$ formation. For these materials diffusion in the solid limits the rate of $\mathrm{NH}_{3}$ liberation. The nitride ionicity $(9.96-68.83 \%$ relative to an ideal ionic solid) was found to correlate with the diffusion constants $\left(6.56 \times 10^{-14}\right.$ to $\left.4.05 \times 10^{-7} \mathrm{~cm}^{2} \mathrm{~s}^{-1}\right)$ suggesting that the reduction of $\mathrm{H}_{2} \mathrm{O}$ over nitrides yielding $\mathrm{NH}_{3}$ is governed by the activity of the lattice nitrogen or ion vacancies, respectively. The ionicity appears to be a useful rationale when developing an atomic-scale understanding of the solid-state reaction mechanism and when designing prospectively optimized ternary nitrides for producing $\mathrm{NH}_{3}$ more sustainably and at mild conditions compared to the Haber Bosch process.
\end{abstract}


*) Corresponding Author: e-mail: pfromm@ksu.edu; phone: +1 785-532-4312; fax: +1 $785-532-7372$

\#) Current address: Brown University, School of Engineering, Box D, 182 Hope Street, Providence, RI 02912, United States

Keywords: Solar radiation, Heterogeneous catalysis, Transition metal nitride, Transition metal oxide, Nitrogen diffusion, Mulliken population analysis 


\section{Introduction}

Energy, water, and food have been cited by Nobel laureate R. Smalley in order of priority as the top three problems that mankind will face in the next decades ${ }^{1}$. Solar energy is essentially inexhaustible and environmentally benign. Employing solar energy to solve society's most demanding challenges, however, requires efficient harvesting of this relatively dilute, intermittent, and geographically non-homogeneous energy source ${ }^{2}$.

Man-made ammonia $\left(\mathrm{NH}_{3}\right)$ has been recognized as to some extent responsible for the "green revolution" of the first half of the $20^{\text {th }}$ century. In other words, it provides the basis of nutrition for a large portion of the human population on earth. Global production of $\mathrm{NH}_{3}$ is currently about 130 million metric tons (t) annually ${ }^{3}$. Ammonia is produced industrially via heterogeneous catalysis that cleaves $\mathrm{N}_{2}$ and hydrogenates nitrogen to $\mathrm{NH}_{3}$ in a single step conducted at some of the most severe conditions in the chemical industry of up to $30 \mathrm{MPa}$ and $500^{\circ} \mathrm{C}^{4}$. The compression work required for the technically sophisticated synthesis accounts for about $16 \%$ of the $28-37 \mathrm{GJ} \mathrm{t}^{-1} \mathrm{NH}_{3}$ consumed by the process ${ }^{5}$. Approximately $45 \%$ of the global $\mathrm{H}_{2}$ production is absorbed as feedstock in the synthesis of $\mathrm{NH}_{3}{ }^{6}$. The $\mathrm{H}_{2}$ feedstock is generated on-site from fossil resources (mainly natural gas, coal or Naphtha), leading to significant fossilbased $\mathrm{CO}_{2}$ emissions ${ }^{4}$ and production of $\mathrm{NH}_{3}$ in a few hundred large-scale centralized facilities world-wide ${ }^{7}$. Given the increasing global population and the potential of $\mathrm{NH}_{3}$ as a "perfect hydrogen carrier" ${ }^{\prime, 9}$ and as a convenient alternative fuel in compression-ignition engines ${ }^{10,11}$, direct synthesis of $\mathrm{NH}_{3}$ from $\mathrm{N}_{2}, \mathrm{H}_{2} \mathrm{O}$ and sunlight may contribute to a sustainable solution to two of our most demanding challenges, energy and food.

Substantial research efforts have pursued the synthesis of $\mathrm{NH}_{3}$ at ambient pressure ${ }^{7} . \mathrm{NH}_{3}$

has been synthesized electrochemically or electrocatalytically ${ }^{12-16}$, e.g., at the cathode of an electrochemical cell that is cleaving $\mathrm{N}_{2}{ }^{13}$ and $\mathrm{H}_{2} \mathrm{O}$ to generate $\mathrm{O}^{2-}$ which is oxidized at the anode 
to $\mathrm{O}_{2}{ }^{15}$. Alternatively, homogeneous catalysis via $\mathrm{N}_{2}$ reduction with transition metal complexes that give substantial yields of $\mathrm{NH}_{3}$ when reacted with acid or $\mathrm{H}_{2}$ has attempted to mimic the enzymatic catalysis of $\mathrm{N}_{2}$ fixation in the liquid phase ${ }^{17-20}$. Albeit promising, both approaches have not yet reached maturity. Electrochemical synthesis relies on electricity and requires novel electrolyte and electrode materials to increase $\mathrm{NH}_{3}$ formation rates ${ }^{15}$. A major obstacle of the biomimetic approach ${ }^{18}$ is the external reducing equivalent (mostly a sacrificial alkali metal or $\mathrm{pH}$ adjustment) that is required for generating the dinitrogen complex from a high oxidation state halide complex ${ }^{17-19}$.

This work pursues an alternative strategy that separates the $\mathrm{N}_{2}$ cleavage from the nitrogen protonation (Scheme 1). Conceptually (with generalized stoichiometry), an oxidized inorganic material $\left(M_{c} O_{d}\right)$ can be reduced with a suitable reducing agent $(R)$ at elevated temperatures:

$$
\frac{a}{b c} M_{c} O_{d}+\frac{a d}{b c} R \leftrightarrow \frac{a}{b} M+\frac{a d}{b c} R O
$$

with $M$ being a metal and lower case letters indicating stoichiometric coefficients. The reaction accomplishes storage of the $2 p$ electrons of oxygen in the metal. This can be achieved with concentrated solar radiation ${ }^{2}$, that is, harvesting photons from the entire insolation spectrum as reducing equivalents ${ }^{21-24}$. Dependent on the free energy of formation of the metal, the remaining reducing equivalents required for the thermochemical charge transfer are supplied by a relatively weak reducing agent ${ }^{18,25}$. This may be $\mathrm{H}_{2}$ or biomass with syngas as a beneficial co-product ${ }^{26-28}$.

The generated reactant can thereafter provide the reducing power for the six-electron reductive cleavage of $\mathrm{N}_{2}$ (forming $\mathrm{N}^{3-}$ ions in the solid state) and splitting of $\mathrm{H}_{2} \mathrm{O}$ (yielding the metal oxide, the desired $\mathrm{NH}_{3}$, and possibly $\mathrm{H}_{2}$ ) without electricity or a fossil fuel:

$$
\frac{a}{b} M+\frac{1}{2} N_{2} \leftrightarrow \frac{1}{b} M_{a} N_{b}
$$




$$
\frac{1}{b} M_{a} N_{b}+\frac{a d}{b c} H_{2} O \leftrightarrow \frac{a}{b c} M_{c} O_{d}+N H_{3}+\left(\frac{a d}{b c}-\frac{3}{2}\right) H_{2}
$$

This separation of $\mathrm{N}_{2}$ cleavage and protonation allows optimizing the equilibrium positions and kinetics of each reaction conducted at favorable temperatures and near $0.1 \mathrm{MPa}$.

Previous studies have outlined the likely economic competiveness of this concept ${ }^{26,28,29}$. Realization of the reaction cycle, however, requires research for a reactive material that balances conflicting thermochemical properties and technical requirements ${ }^{28}$. These are in particular: (i) acceptable yields and kinetics of the $\mathrm{N}_{2}$ reduction and protonation of the lattice nitrogen near 0.1 $\mathrm{MPa}$, (ii) reduction of the oxidized reactant (recycling) at temperatures that can be contained physically in an industrial-scale solar furnace (preferably below $1500^{\circ} \mathrm{C}$ ), (iii) use of moderate quantities of a sustainable reducing agent, and (iv) significant energy conversion efficiencies (comparing raw materials plus solar energy with the energy contained in the $\mathrm{NH}_{3}$ and perhaps syngas produced). The "degree of freedom" to control the reduction temperature and the quantities of reducing agent and byproducts by adjusting the reactant composition is illustrated with supporting material for this paper that is available online. Here the hydrolysis yield and kinetics, and the impact of this step on the overall process efficiency are the main subjects.

\section{Thermochemical theory and reaction mechanism}

\subsection{Materials composition determining energy conversion efficiencies}

Figure 1A maps the ratios of heat released during the $\mathrm{N}_{2}$ reduction or $\mathrm{NH}_{3}$ formation relative to the energy absorbed in the oxide reduction for various binary nitride/oxide pairs ${ }^{28,30}$. The calculation indicates high theoretical ratios of the heating value of the generated solar-based

energy carrying molecules ${ }^{31}\left(\mathrm{NH}_{3}\right.$ and syngas) to the supplied solar and chemical energy of about 52 to $85 \%$. This worst case assumes no in-process heat recovery, separate metal reduction and nitridation, and use of nitrides that are expected to yield ammonia. 
Predominantly ionic nitrides (e.g., $\mathrm{Mg}_{3} \mathrm{~N}_{2}$ or $\mathrm{Ca}_{3} \mathrm{~N}_{2}$ ) liberate large quantities of heat during their hydrolysis (Fig.1A). This limits their attractiveness for the proposed concept since this energy can not be easily integrated at the higher temperatures required for the endothermic oxide reduction step. On the other hand, binary transition metal nitrides with relatively high $\mathrm{NH}_{3}$ equilibrium yields (e.g., $\mathrm{Mn}_{4} \mathrm{~N}$ or $\mathrm{Nb}_{2} \mathrm{~N}$, Fig.1B) will require large quantities of chemical reducing agent due to unfavorable stoichiometric compositions (e.g., 4 mol C per mol $\mathrm{NH}_{3}$ for a $\mathrm{Mn}_{4} \mathrm{~N} / \mathrm{MnO}$ reactive material relative to $3 / 2 \mathrm{~mol} \mathrm{C}$ per mol $\mathrm{NH}_{3}$ for a $\mathrm{Mg}_{3} \mathrm{~N}_{2} / \mathrm{MgO}$ reactant). Although well-studied for their refractory properties ${ }^{32,33}$ hydrolysis of nitrides and $\mathrm{NH}_{3}$ formation kinetics have been rarely reported ${ }^{27,34-36}$. Pourbaix diagrams providing information on corrosion mechanisms are typically only available for pure elements ${ }^{37}$. Bonding in metal nitrides appears not well understood ${ }^{38}$.

Determining an optimum reactant composition is a complex task of balancing contradictory requirements. Finding trends in the chemical reactivity and reaction kinetics is an essential first step in understanding material properties and in rational materials design ${ }^{39}$. Figure 2 shows that a higher number of $\mathrm{d}$ electrons correlates with reduced stability of the nitride due to the higher number of electrons in nonbonding orbitals weakening the metal-nitrogen bond ${ }^{39}$. Recognizing that this bond ${ }^{38}$ has to be stable enough to reduce $0.1 \mathrm{MPa} \mathrm{N}_{2}$ but weak enough ${ }^{28}$ to avoid excessive liberation of heat during hydrolysis illustrates the importance of understanding the electronic structure $e^{7,39,40}$ of the metal-nitrogen bond. This will be inevitable for the design of a novel, perhaps ternary ${ }^{41}$, optimized reactant for the reactive $\mathrm{NH}_{3}$ synthesis.

\subsection{Possible reaction mechanism}

In lieu of a complete quantitative description of the overall $\mathrm{NH}_{3}$ formation mechanism, which exceeds the scope of this work, a schematic of the hypothetical reaction mechanism is given in Chart 1 . The overall process converting $\mathrm{N}^{3-}$ ions and $\mathrm{H}_{2} \mathrm{O}$ to $\mathrm{O}^{2-}$ and $\mathrm{NH}_{3}$ is envisioned 
as a succession of six steps: Water is (1) assumed to be adsorbed by a vacant surface site on the metal oxide and, thereafter, due to (2) diffusion of metal ions and electrons through the oxide, (3) reduced to $\mathrm{H}^{+}$and $\mathrm{OH}^{-}$. This forms a metal hydroxide that may decompose to an oxide at elevated temperatures. The continuous growth of the oxide shell is enabled by (4) diffusion of nitrogen and oxygen through the oxide. The liberated nitrogen ion is (5) protonated to $\mathrm{NH}_{3}$ and, depending on the Brønsted acidity of the metal ions ${ }^{36}$, (6) desorbed from the oxide surface.

As a starting point, the present study evidences the diffusion of lattice nitrogen through the oxide and attempts to characterize its effect on the $\mathrm{NH}_{3}$ formation kinetics. Section 4.1 and 4.2 characterize the kinetics of the $\mathrm{NH}_{3}$ formation via hydrolysis of seven nitrides with different bonding properties. The efficiency of liberating the lattice nitrogen and protonating it to $\mathrm{NH}_{3}$ is addressed in Section 4.3. Section 4.4 introduces the nitride ionicity as a rationale to screen for optimized reactants. Correlating the partial electric charge of the lattice nitrogen to the reaction characteristics of the bulk material will be shown to enable an atomic-scale understanding of the reaction mechanisms and activation barriers in the future.

\section{Experimental}

\subsection{Metal nitridation}

The nitrides of $\mathrm{Ca}$, Mn and Mo were prepared (Fig. 3$)^{38}$ from ca. $2 \mathrm{~g}$ of metal powder heated from $400^{\circ} \mathrm{C}$ to $700^{\circ} \mathrm{C}(\mathrm{Mn})$ or $750^{\circ} \mathrm{C}(\mathrm{Ca}, \mathrm{Mo})^{42}$ in a quartz boat inside of a tube furnace (60 mm ID, 1 m length, quartz, model HTF55347C, temperature controller model CC58434C, Lindberg/Blue). Mn and Mo were pre-treated at $60^{\circ} \mathrm{C}$ for $10 \mathrm{~min}$ to remove water. The heating rate $r_{H}$ can be represented as $r_{H}=\mathrm{A} t+\mathrm{B}$, where $t$ is the heating time in min, $\mathrm{A}=-9.29^{\circ} \mathrm{C} \min ^{-2}$, and $\mathrm{B}=82.1^{\circ} \mathrm{C} \min ^{-1}\left(R^{2}>0.90\right) . \mathrm{N}_{2}$ was always supplied at $0.1 \mathrm{MPa}$, i.e., $1.83 \pm 0.021_{(\mathrm{STP})} \mathrm{N}_{2}$ $\min ^{-1}(\mathrm{Ca}, \mathrm{Mn})$, or diluted with $\mathrm{H}_{2}$, i.e., $1.09 \pm 0.01 \mathrm{l}_{(\mathrm{STP})} \mathrm{N}_{2} \min ^{-1}$ mixed with $0.364 \pm 0.003$ 
$1_{(\mathrm{STP})} \mathrm{H}_{2} \min ^{-1}(\mathrm{Mo})$. The nitridation temperature was held for $120(\mathrm{Mn}), 180(\mathrm{Mo})$ or $240 \mathrm{~min}$ (Ca) respectively and cooling was at about $-4.87^{\circ} \mathrm{C} \mathrm{s}^{-1}$ at $<1 \mathrm{~min},-50.6^{\circ} \mathrm{C} \mathrm{min}^{-1}$ at $1 \mathrm{~min}$ to $\leq 10$ min, and $-3.63^{\circ} \mathrm{C} \min ^{-1}$ at $>10 \mathrm{~min}$. The $\alpha-\mathrm{Ca}_{3} \mathrm{~N}_{2} / \mathrm{Ca}_{2} \mathrm{~N}$ product was milled with pestle and mortar. All Ca-containing chemicals were handled and stored under Ar. All solids were stored under $\mathrm{Ar}$ or $\mathrm{N}_{2}$ at $4^{\circ} \mathrm{C}$.

\subsection{Metal nitride hydrolysis}

To describe the reaction kinetics of the lattice nitrogen seven metal nitrides (Table 1) with varying bonding character were reacted at three different temperatures with steam (Fig.3). To remove residual $\mathrm{O}_{2}$ the furnace was purged for ca. $10 \mathrm{~min}$ with $0.5-0.9 \mathrm{l}_{(\mathrm{STP})} \mathrm{N}_{2} \mathrm{~min}^{-1}$ before each experiment. Nitride powder was placed into a quartz boat $\left(0.5 \mathrm{~g}\right.$, except $1 \mathrm{~g} \mathrm{Cr}_{2} \mathrm{~N}$, i.e., $5.82 \times 10^{-1}$ to $1.23 \times 10^{1} \mathrm{mmol}$ total lattice nitrogen), introduced at $100^{\circ} \mathrm{C}$ into the furnace, and heated to $200-1000^{\circ} \mathrm{C}$. Heating rates $r_{H}$ can be approximated $\left(R^{2}=0.75-0.83\right.$, see Section 3.1$)$ with $\mathrm{A}=-$ $6.85^{\circ} \mathrm{C} \min ^{-2}$ and $\mathrm{B}=50.2^{\circ} \mathrm{C} \min ^{-1}$ (at $200-300^{\circ} \mathrm{C}$ ), $\mathrm{A}=-4.23^{\circ} \mathrm{C} \min ^{-2}$ and $\mathrm{B}=61.4^{\circ} \mathrm{C} \min ^{-1}$ $\left(500-600^{\circ} \mathrm{C}\right)$, or $\mathrm{A}=-3.59^{\circ} \mathrm{C} \min ^{-2}$ and $\mathrm{B}=82.8^{\circ} \mathrm{C} \mathrm{min}^{-1}\left(1000^{\circ} \mathrm{C}\right)$ respectively. Final temperatures were held for $60 \mathrm{~min}$ and steam was supplied at $0.8 \pm 0.1 \mathrm{ml}_{(\mathrm{STP})} \mathrm{H}_{2} \mathrm{O} \mathrm{min}{ }^{-1}$.

The gas leaving the furnace was routed through a liquid absorbent ( $25 \pm 5 \mathrm{ml}_{\text {(STP) }}$ ice-cold $10 \mathrm{mM} \mathrm{HCl}$ ). To estimate the yield of absorbed $\mathrm{NH}_{4}{ }^{+}, 5 \mathrm{ml}$ samples were taken at $0,1,5,10$ and $60 \pm 0.5 \min \left(\mathrm{Mg}_{3} \mathrm{~N}_{2}, \mathrm{AlN}, \mathrm{Ca}_{3} \mathrm{~N}_{2}\right.$, and $\left.\mathrm{Zn}_{3} \mathrm{~N}_{2}\right)$ or 0 (this includes the heating phase), 5, 10, 30 and $60 \pm 0.5 \min \left(\mathrm{Cr}_{2} \mathrm{~N}, \mathrm{Mn}_{4} \mathrm{~N}\right.$, and $\left.\mathrm{Mo}_{2} \mathrm{~N}\right)$ after the reaction temperature was reached. After 60 min the furnace was opened and cooled (at -0.90 to $-8.7{ }^{\circ} \mathrm{C} \mathrm{s}^{-1}$ at $<10 \mathrm{~min},-8.8$ to $-82{ }^{\circ} \mathrm{C} \mathrm{min}^{-1}$ at $<10 \mathrm{~min}$, and -1.1 to $-18^{\circ} \mathrm{C} \mathrm{min}^{-1}$ at $>10 \mathrm{~min}$ ) to below $100^{\circ} \mathrm{C}$. All solids were stored under $\operatorname{Ar}\left(\mathrm{Mg}_{3} \mathrm{~N}_{2}, \mathrm{Ca}_{3} \mathrm{~N}_{2}\right)$ or air at $4^{\circ} \mathrm{C}$. All liquids were stored at room temperature. 


\subsection{Solid state analysis}

Powder X-ray diffraction (XRD, Miniflex II diffractometer, Cu-target X-ray tube, $30 \mathrm{kV} /$ $15 \mathrm{~mA}$ output, diffracted beam monochromator, Rigaku) was used (5-80 ${ }^{\circ} 2 \theta$ range, 1 or 10 ${ }^{\circ} 2 \theta /$ min scan speed, 0.02 data points $/{ }^{\circ} 2 \theta$, continuous mode) for quantitative solid phase identification (PDXL Software Version 1.6.0.0). To confirm metal nitridation energy-dispersive X-ray spectroscopy (EDS) was employed using scanning electron microscopy (SEM) (20 keV, S3500N, Hitachi; Link Pentafet 7021 X-ray detector and Inca Energy X-ray analysis software, both Oxford Instruments). Nitride particles were imaged by SEM before and after reacting with steam at $500^{\circ} \mathrm{C}$. All weights were determined using an AE260 DeltaRange balance $( \pm 0.1 \mathrm{mg}$, Mettler). The specific BET surface area was analyzed by NanoScale Inc., Manhattan, KS.

\subsection{Liquid and gas phase analysis}

$\mathrm{NH}_{3}$ absorbed by the liquid absorbent was analyzed in triplicate with an $\mathrm{NH}_{3}$ Ion Selective Electrode and a pH/ISE Controller (model 270) (both Denver Instrument), combined with the liquid level in the absorption vessel (error ca. $\pm 5 \mathrm{ml}$ ). The uncertainty of $\mathrm{NH}_{3}$ concentrations was estimated as the average of one standard deviation of about 65 liquid samples analyzed in triplicate. The outlet of the absorption vessel was equipped with an $\mathrm{NH}_{3}$ gas detection tube (0.25-3 or 5-70 $\mathrm{ppm} \mathrm{NH}_{3}$ detection range, Dräger).

\subsection{Chemicals}

Solid chemicals were AlN (99.8\% pure, -325 mesh), Mn metal (99.9\% pure, -325 mesh), $\mathrm{Zn}_{3} \mathrm{~N}_{2}$ (99.9\% pure, -200 mesh), and Mo metal (99.95\% pure, -325 mesh) all from Noah Technologies; Ca metal (99\% pure, granular) and $\mathrm{NH}_{4} \mathrm{Cl}(99.5 \%$, extra pure) both from Acros Organics; $\mathrm{Mg}_{3} \mathrm{~N}_{2}$ (99.6\% pure, -325 mesh, AlfaAesar); $\mathrm{Cr}_{2} \mathrm{~N}$ (98\% pure, -100 mesh, Prochem); and $\mathrm{NaOH}(99.6 \%$, certified ACS pellets, Fisher Scientific). Glassware was cleaned with acetone (certified ACS, Fisher Scientific). All gases $\left(\mathrm{H}_{2}, \mathrm{~N}_{2}\right.$, and Ar) were UHP Zero grade (Linweld). 
$\mathrm{H}_{2} \mathrm{O}$ was deionized (Direct-Q $3 \mathrm{UV}$, Millipore) and degassed with Ar. $\mathrm{HCl}(12.1 \mathrm{~N}$, certified ACS Plus) was from Fisher Scientific.

\subsection{Nitride characterization}

Table 1 shows the major bulk nitride phases identified via XRD. The BET specific surface area of the materials is consistent with the literature $27,34,35,42$. The surface area of the nitrides that have been prepared from their elements is of the same order of magnitude as for purchased $\mathrm{Cr}_{2} \mathrm{~N}$ and about one order of magnitude below the specific surface area of $\mathrm{Mg}_{3} \mathrm{~N}_{2}, \mathrm{AlN}$ and $\mathrm{Zn}_{3} \mathrm{~N}_{2}$. Whether this may affect $\mathrm{NH}_{3}$ yields is addressed in Section 4.2. Values of the partial electronic charge of the lattice nitrogen ${ }^{43-53}, q_{N}$, are summarized in Table 2.

\subsection{Data processing}

To determine the hydrolysis reaction kinetics, the yield of $\mathrm{NH}_{3}, X_{N H 3}$, is reported as molar ratio of $\mathrm{NH}_{3}$ captured by the acidic absorbent ( $n$ in mol) at a given time, $t$, relative to the lattice nitrogen of the reactant before the reaction:

$$
X_{N H_{3}}=\frac{n_{\text {absorbed } N H_{3}, t}}{n_{N}}=\frac{\sum_{t=0-60 \min }\left(c_{N H_{3}, t}-c_{N H_{3}}^{*}\right) V_{t}}{m_{r} \sum_{i=\text { all nitrides }} b_{i} x_{i} M_{i}^{-1}}
$$

where $c_{N H 3}$ in mol L-1 is the concentration of $\mathrm{NH}_{3}$ detected in the absorbent, the asterisk marks pure water used as a reference, $V$ in $\mathrm{L}$ is the sample volume, $m_{r}$ in $\mathrm{g}$ is the mass of metal nitride powder reacted, $b$ is a stoichiometric coefficient (see Eq.3), $x$ in $\mathrm{g} \mathrm{g}^{-1}$ is the nitride weight fraction (Table 1), and $M$ in $\mathrm{g} \mathrm{mol}^{-1}$ is the molar mass. The initial reaction rate, $r_{0}$, is calculated analogously from a tangent to the data point collected at $\Delta t=5 \mathrm{~min}$. 


\section{Results and Discussion}

\section{1 $\mathrm{NH}_{3}$ liberation kinetics from $\mathrm{p}$ - and d-block nitrides}

It is of utmost importance to determine limiting processes that impede a rapid and efficient conversion from nitride to ammonia. The rate-limiting process of a heterogeneous reaction may be mass transfer or chemical reaction, $k_{r}$, where $k$ marks a specific rate constant. Mass transfer by diffusion occurs in the gas phase, described by $k_{g}$, or in the solid phase, $k_{s}$. To determine the rate-limiting step three shrinking-core models for spherical particles of unchanging size $^{54}$ were applied:

$$
\begin{aligned}
& k_{g} t=X_{N H_{3}} \\
& k_{s} t=1-3 \times\left(1-X_{N H_{3}}\right)^{2 / 3}+2 \times\left(1-X_{N H_{3}}\right) \\
& k_{r} t=1-\left(1-X_{N_{3}}\right)^{1 / 3}
\end{aligned}
$$

The specific rate constants fitted ${ }^{23,34}$ in the time interval $\Delta t_{f i t}$ with a maximum $R^{2}$ are summarized in Table 3. Representative graphs of the $\mathrm{NH}_{3}$ yield versus the reaction time (at the temperature that resulted in maximum $X_{N H 3}$ ) are given in Figure 4. As an aside, the yield of $\mathrm{NH}_{3}$ after $60 \mathrm{~min}$ is in most cases below the yield determined after 10 or 30 min respectively. This is presumably due to unwanted stripping of the absorbent by the steam routed from the reactor through the wash bottle after the reactor. Based on minimizing the residual sum of squares between the experimental data and the employed shrinking core models, a solid-state diffusion limitation (Eq.6) describes the formation of $\mathrm{NH}_{3}$ from the tested p- and d-block nitrides (with few exceptions, see Table 3) best.

Solid-state diffusion limited $\mathrm{NH}_{3}$ formation (Chart 1) is in agreement with the low yield of $\mathrm{NH}_{3}$ via corrosion of chromium nitrides or stainless steel with dissolved nitrogen ${ }^{27,33}$. The $\mathrm{NH}_{3}$ formation from $\mathrm{Mn}_{4} \mathrm{~N}, \mathrm{Zn}_{3} \mathrm{~N}_{2}$ and of $\beta-\mathrm{Mo}_{2} \mathrm{~N}^{55}$ appears to follow a diffusion limited mechanism over a relative broad range of reaction temperatures and times. Hydrolysis of hot pressed AlN 
particles has been found to yield only $0.3 \% \mathrm{Al}_{2} \mathrm{O}_{3}$ after $30 \mathrm{hrs}$ at $1000^{\circ} \mathrm{C}^{32}$. Also, a $2 \mathrm{~mol} \%$ oxidation of fine AlN powder has been reported when hydrolyzing the nitride for $60 \mathrm{~min}$ at $900^{\circ} \mathrm{C}^{34}$. On the other hand, $\mathrm{NH}_{3}$ from $\mathrm{AlN}$ and $\mathrm{H}_{2} \mathrm{O}$ at below $100^{\circ} \mathrm{C}^{35}$ and up to $70 \mathrm{~mol} \%$ conversion via hydrolysis for $60 \mathrm{~min}$ at $1000^{\circ} \mathrm{C}$ have been reported as well $1^{34}$. This demonstrates the hydrolysis of the corrosion-resistant AlN depends significantly on the steam temperature (Table 3) and pressure, and the nitride particle size ${ }^{32,34,35}$. Liberation of $\mathrm{NH}_{3}$ from AlN is represented well by a solid-state diffusion limited process (Table 3).

Supporting liberation of nitrogen from the bulk, projecting the nitride unit cells on the BET surface area of the bulk material allows an estimate of the maximum yield of a pure surface reaction (independent of the orientation of the crystal facets) with $0.07-0.80 \mathrm{~mol} \% \mathrm{~N}$ from $\mathrm{Mn}_{4} \mathrm{~N}$, $\mathrm{CrN}, \mathrm{Cr}_{2} \mathrm{~N}, \mathrm{Mn}_{6} \mathrm{~N}_{2.58}, \mathrm{Mo}_{2} \mathrm{~N}$, AlN or $2.34 \mathrm{~mol} \% \mathrm{~N}$ from $\mathrm{Zn}_{3} \mathrm{~N}_{2}$ respectively. Compared to the higher yields of lattice nitrogen found here (Fig.4) this supports the formation of $\mathrm{NH}_{3}$ from the bulk of these materials involving the transport of lattice nitrogen from the bulk (approximately 13-490 $\mathrm{nm}$ below the particle surface) to the solid/gas interface.

In summary, diffusion limitations in the solid state appear to be the most plausible kinetic limitation for the $\mathrm{NH}_{3}$ liberation via $\mathrm{H}_{2} \mathrm{O}$ splitting over nitrides of $\mathrm{Al}, \mathrm{Cr}, \mathrm{Mn}, \mathrm{Zn}$, or Mo.

\section{2 $\mathrm{NH}_{3}$ liberation kinetics from s-block nitrides}

A case will be made that hydrolysis of $\mathrm{Mg}_{3} \mathrm{~N}_{2}$ or $\mathrm{Ca}_{3} \mathrm{~N}_{2}$ respectively appears to follow a mechanism that is limited by gas phase diffusion (Eq.5) rather than solid-state diffusion. Opposed to the hydrolysis of $\mathrm{Zn}_{3} \mathrm{~N}_{2}$ (Fig.4), diffusion limitation in the gas phase represents the liberation of $\mathrm{NH}_{3}$ from $\mathrm{Mg}_{3} \mathrm{~N}_{2}$ or $\mathrm{Ca}_{3} \mathrm{~N}_{2}$ respectively best at all tested temperatures (Table 3).

The minimum initial reaction rates for these nitrides at $300^{\circ} \mathrm{C}$ may originate from the opposing effects of high reactant concentrations at low temperatures (about 25-16 $\mathrm{mol} \mathrm{H}_{2} \mathrm{O} \mathrm{m}^{-3}$ at $200-500^{\circ} \mathrm{C}$, assuming an ideal gas) and short residence times of the meta-stable $\mathrm{NH}_{3}$ product at 
high temperatures (about $13-8 \mathrm{~s}$ at $200-500^{\circ} \mathrm{C}$ ). Furthermore, accounting for the difference in the average particle diameter, $d_{p},\left(k_{g} \sim d_{p}^{-1}\right)^{54}$ between $\mathrm{Mg}_{3} \mathrm{~N}_{2}$ and $\mathrm{Ca}_{3} \mathrm{~N}_{2}$ particles (Table 1) yields a "corrected" specific rate constant $k_{g}$ for $\mathrm{Ca}_{3} \mathrm{~N}_{2}$ in the range of 0.47-1.72 times $k_{g}$ for $\mathrm{Mg}_{3} \mathrm{~N}_{2}$. Thus, the delayed $\mathrm{NH}_{3}$ formation observed during the hydrolysis of $\mathrm{Ca}_{3} \mathrm{~N}_{2}$ can be explained to a large part with the difference in specific surface area available for the reaction. Previous studies of the $\mathrm{Mg}_{3} \mathrm{~N}_{2}$ decomposition described the formation of chemisorbed $\mathrm{NH}_{4}{ }^{+}$as not limited by solid-state diffusion ${ }^{36}$ and reported specific rate constants of the $\mathrm{Mg}_{3} \mathrm{~N}_{2}$ hydrolysis on the same order as those reported here, which supports our interpretation.

$\mathrm{NH}_{3}$ formation without solid-state diffusion control for $\mathrm{Mg}_{3} \mathrm{~N}_{2}$ or $\mathrm{Ca}_{3} \mathrm{~N}_{2}$ respectively is supported in addition by a correlation between the specific rate constant and the specific volumes of nitrides and the solid reaction products (Fig.5). This can be rationalized as particle breakup due to volume changes during the reaction (Fig.5). The reaction products were mixtures of the reacted metals, nitrides, and $\mathrm{Mg}(\mathrm{OH})_{2} / \mathrm{MgO}, \mathrm{Al}(\mathrm{OH})_{3} / \mathrm{Al}_{2} \mathrm{O}_{3}, \mathrm{Ca}(\mathrm{OH})_{2} / \mathrm{CaO}, \mathrm{Cr}_{2} \mathrm{O}_{3}, \mathrm{MnO} / \mathrm{Mn}_{3} \mathrm{O}_{4}, \mathrm{ZnO}$, or $\mathrm{MoO}_{3} / \mathrm{MoO}_{2}$ (where the presence of the second solid in each pair increased with increasing temperature). $\mathrm{Mg}_{3} \mathrm{~N}_{2}$ or $\mathrm{Ca}_{3} \mathrm{~N}_{2}$ particles were decreased by about 89 or $57 \%$ in diameter after hydrolysis, respectively. This can be explained with a specific volume increase from reactants to products. Hydrolysis of $\mathrm{Zn}_{3} \mathrm{~N}_{2}$ led only to crevice formation (see additional online materials).

The activation energies of the $\mathrm{NH}_{3}$ liberation (determined from Arrhenius plots of the specific rate constants given in Table 3) for $\mathrm{Mg}_{3} \mathrm{~N}_{2}$ or $\mathrm{Ca}_{3} \mathrm{~N}_{2}$ respectively are low, in the range of 9-14 $\mathrm{kJ} \mathrm{mol}^{-1}$. This is additional support for the assumed gas phase diffusion limitation since typical activation energies for solid-state diffusion limited processes are about $60 \mathrm{~kJ} \mathrm{~mol}^{-1}$ for the diffusion of $\mathrm{Mn}^{2+}, \mathrm{Mn}^{3+}$, or $\mathrm{Mn}^{4+}$ vacancies during the oxidation of $\mathrm{Mn}_{3} \mathrm{O}_{4}{ }^{56}$ or about $135 \mathrm{~kJ} \mathrm{~mol}^{-}$

${ }^{1}$ (about $1.4 \mathrm{eV}$ in average for a particle grain size $\geq 1 \mu \mathrm{m}$ ) for conduction in $\alpha-\mathrm{Al}_{2} \mathrm{O}_{3}{ }^{57}$. The 
approximate activation energies of $63,92,69$, or $106 \mathrm{~kJ} \mathrm{~mol}^{-1}$ for the hydrolysis of $\mathrm{Mn}_{4} \mathrm{~N}, \mathrm{Cr}_{2} \mathrm{~N}$, $\mathrm{Zn}_{3} \mathrm{~N}_{2}$ or AlN are within this range indicating solid-state diffusion limitation.

The observations and arguments above support that physical particle disintegration is likely the reason for the absence of solid-state diffusion limitations during the hydrolysis of the two tested highly ionic nitrides, $\mathrm{Mg}_{3} \mathrm{~N}_{2}$ or $\mathrm{Ca}_{3} \mathrm{~N}_{2}$. It will be shown in Section 4.4 that the solidstate diffusion limitations during the hydrolysis of the tested p- and d-block nitrides can be rationalized with the nitride ionicity.

\subsection{Nitrogen mass balance}

The nitrogen mass balance (Fig.4) neglects the relatively small amount of $\mathrm{NH}_{3}$ detected in

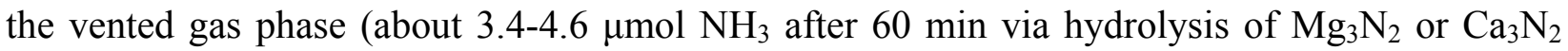
respectively). Figure 4 shows that all ionic nitrides are nearly completely oxidized after $60 \mathrm{~min}$ under steam. At $500^{\circ} \mathrm{C} 27-70 \mathrm{~mol} \%$ of the removed $\mathrm{N}^{3-}$ is recovered as $\mathrm{NH}_{3}$. All other nitrides except $\mathrm{Mn}_{4} \mathrm{~N}$ liberated less than $50 \mathrm{~mol} \%$ of the lattice nitrogen with up to $17 \mathrm{~mol} \%$ recovered as $\mathrm{NH}_{3}$, except $41 \pm 3 \mathrm{~mol} \% \mathrm{NH}_{3}$ from $0.80 \pm 0.01 \mathrm{~mol} \%$ nitrogen liberated by $\mathrm{AlN}$ at $300^{\circ} \mathrm{C}$ or 60 $\pm 5 \mathrm{~mol} \% \mathrm{NH}_{3}$ from $23 \pm 2 \mathrm{~mol} \%$ nitrogen liberated by $\mathrm{Mo}_{2} \mathrm{~N}$ at $500^{\circ} \mathrm{C}$. Formation of $\mathrm{N}_{2} \mathrm{H}_{4}$ from $\mathrm{Mn}_{4} \mathrm{~N}$ was suspected ${ }^{19}$ but back titration of the liquid absorbent did not confirm this (data not shown). The large amount of lattice nitrogen liberated from $\mathrm{Mn}_{4} \mathrm{~N}$ either does not form $\mathrm{NH}_{3}$ effectively or $\mathrm{NH}_{3}$ is formed but not removed quickly enough from the material surface due to Lewis or Brønsted acid-base interactions between manganese oxides, $\mathrm{NH}_{3}, \mathrm{H}_{2} \mathrm{O}$ and the related ionic species.

In summary, the efficient conversion of up to $70 \mathrm{~mol} \%$ nitrogen liberated from ionic nitrides to $\mathrm{NH}_{3}$ is matched in the reported experiments only by about $60 \mathrm{~mol} \% \mathrm{NH}_{3}$ from the nitrogen of $\mathrm{Mo}_{2} \mathrm{~N}$. The low yield of $\mathrm{NH}_{3}$ from manganese nitride will be assessed elsewhere. 


\subsection{Nitride ionicity controlling the solid-state diffusion}

Nitride hydrolysis yielding $\mathrm{NH}_{3}$ is favored by a decrease in free energy (Fig.1B), impaired at elevated temperatures only by thermal decomposition of the nitrides $\mathrm{or}^{\mathrm{NH}_{3}}$ to products and $\mathrm{N}_{2}$. The reaction characteristics reported here are non-equilibrium. Ionic materials such as $\mathrm{Mg}_{3} \mathrm{~N}_{2}$ yield $\mathrm{NH}_{3}$ quickly. Less ionic nitrides such as $\mathrm{Cr}_{2} \mathrm{~N}$ liberate $\mathrm{NH}_{3}$ slowly and only at elevated temperatures.

Attempting a relative comparison of the nitride hydrolysis data (Table 3 ), ionicity, $i_{N}$, here defined as the partial nitrogen charge ${ }^{43-53}$ (Table 2) relative to a theoretical -3 oxidation state of the lattice nitrogen, $i_{N}=q_{N} /(-3)$, can be correlated with the specific rate constants $k_{s}$ (Fig.6). This shows a promotion of the reaction kinetics by the partial electric charge of the lattice nitrogen, leveling off at about 35\% ionicity (arrow, Fig.6). As reported for the diffusion of nitrogen or carbon in other solid-state processes ${ }^{58}$, the effective diffusion coefficient appears dependent on the activity of the lattice nitrogen.

Limiting the focus on the p- and d-block nitrides (see Section 4.1), the effective chemical diffusion coefficient, $D$ in $\mathrm{m}^{2} \mathrm{~s}^{-1}$, is given with ${ }^{54}$ :

$$
D=\frac{a d}{24 c} \frac{\rho_{\text {nitride }} k_{s} d_{p}^{2}}{\rho_{\text {steam }}} \approx 8.54 \times 10^{-23} \exp \left(1.24 \times 10^{2} \times i_{N}\right)
$$

where $a, c$, and $d$ are stoichiometric coefficients (Eq.3) and $\rho_{\text {nitride }}$ and $\rho_{\text {steam }}$ are the molar densities of the solid and gaseous reactants at $500^{\circ} \mathrm{C}$ in $\mathrm{mol} \mathrm{m}^{-3}$ respectively. Figure 7 shows a plot of the diffusion coefficient versus the nominal radius of a single metal ion ${ }^{6}$ (Fig.7A) or the nitride ionicity respectively (Fig.7B). The apparent bulk diffusion coefficient does not correlate with the nominal radius of a single metal ion but yields a nearly quantitative correlation $\left(R^{2}>\right.$ $0.97)$ with the nitride ionicity. 
For comparison, assuming a diffusion length equal to half the particle diameter yields the characteristic time ${ }^{59}$ for a solid-state diffusion limited process, $t_{D}$, with approximately $d_{p}{ }^{2} /(16 D)$. The characteristic diffusion times (Fig.7B) for $\mathrm{Cr}_{2} \mathrm{~N}, \mathrm{AlN}$, or $\mathrm{Mn}_{4} \mathrm{~N}$ are about 206 days, 7.9 hrs, or 33.7 min respectively. This is by orders of magnitude longer than, e.g., the $0.1-2$ ms range estimated for a solar thermochemical $\mathrm{H}_{2}$ production cycle that had been assessed as not limited by the diffusion of oxygen vacancies in a ceria lattice ${ }^{59}$. The characteristic times for the $\mathrm{NH}_{3}$ liberation from the nitrides with slightly higher ionicity, i.e., $\mathrm{Mo}_{2} \mathrm{~N}$ or $\mathrm{Zn}_{3} \mathrm{~N}_{2}$ with 19.7 or $2.16 \mathrm{~s}$ respectively, are significantly shorter. This supports the inferred link between solid-state diffusion-controlled $\mathrm{NH}_{3}$ formation and the ionicity, i.e., the partial charge of the nitrogen atom.

The diffusion coefficient is increasing with increasing ionicity suggesting that the size of hypothetical nitrogen ions with effective electric charges below three ${ }^{50}$ is not determining the reaction kinetics. The nitride ionicity and its relation to the diffusion coefficient may be rather understood in terms of ambipolar diffusion that is the coupled migration of nitrogen ions (or vacancies respectively) and electrons under a nitrogen chemical potential gradient ${ }^{59}$. Increasing the nitride ionicity increases the volumetric concentration of reactive lattice nitrogen. This increases the diffusion coefficient (assuming generally a higher mobility of electrons in the conduction band ${ }^{38}$ compared to the mobility of the nitrogen ions).

This dependency of the ammonia formation kinetics on of the nitride ionicity can be used to screen for optimized reactants. The ideal nitride for solar thermochemical $\mathrm{NH}_{3}$ synthesis (see Section 2) has, on one hand, a reasonably stable metal nitrogen bond to enable the reduction of $0.1 \mathrm{MPa} \mathrm{N}_{2}$ (opposed to, e.g., $\mathrm{Zn}_{3} \mathrm{~N}_{2}$ ) without forming highly stable oxides (e.g., $\mathrm{MgO}$ or $\left.\mathrm{Al}_{2} \mathrm{O}_{3}\right)^{28}$. This narrows the focus on the transition metals. On the other hand, efficient and fast protonation of the lattice nitrogen to $\mathrm{NH}_{3}$ requires nitride ionicities between those of $\mathrm{Mo}_{2} \mathrm{~N}$ and $\mathrm{Zn}_{3} \mathrm{~N}_{2}$. The desired optimum may be found by screening the transition metal nitrides for their 
partial electric nitrogen charge and/or by doping nitrides (e.g., those formed by Mo or Mn) with metals that donate additional electrons to the nitrogen without leading to formation of significantly more stable oxides during the hydrolysis (maybe small quantities of early transition metals such as Ti).

\section{Conclusions}

A rationale to design new reactants for solar thermochemical ammonia production from air and water based on ionicity has been developed. The correlation between the nitride ionicity and the effective solid-state diffusion coefficient that limits nitride hydrolysis (ammonia formation) suggests a reaction mechanism governed by the volumetric concentration of active nitrogen ions. Based on $\mathrm{NH}_{3}$ liberation kinetics, the nitrogen mass balance and the minimum heat liberated during the hydrolysis step $\mathrm{Mo}_{2} \mathrm{~N}$ may be a promising major constituent of a reactant for the solar thermochemical $\mathrm{NH}_{3}$ synthesis. Development of manganese-based reactants may benefit from efficient liberation of the lattice nitrogen but will require means to ensure an economic recovery of the nitrogen as $\mathrm{NH}_{3}$.

\section{Associated content}

Supporting Information Available: An Ellingham diagram for the reduction of $\mathrm{MgO}$, $\mathrm{Al}_{2} \mathrm{O}_{3}, \mathrm{CaO}, \mathrm{Cr}_{2} \mathrm{O}_{3}, \mathrm{Mn}_{2} \mathrm{O}_{3}, \mathrm{MnO}, \mathrm{ZnO}, \mathrm{MoO}_{2}$ and the oxidation of various reducing agents vs. temperature, the dependence of the free energy stored in the reaction cycle products $\left(\mathrm{NH}_{3}, \mathrm{H}_{2}\right.$, or $\mathrm{CO}$ ) on the stoichiometric composition of the nitride/oxide reactant, a detailed version of Fig.1A, a plot of the free energy of the $\mathrm{N}^{3-}$ oxidation reaction vs. the electronegativity of the metal constituent of the nitride, a complete version of Fig. 4 providing kinetic $\mathrm{NH}_{3}$ formation data and the nitrogen mass balance, and SEM micrographs of the $\mathrm{Zn}_{3} \mathrm{~N}_{2}$ or $\mathrm{Mo}_{2} \mathrm{~N}$ hydrolysis respectively. This material is available free of charge via the Internet at http://pubs.acs.org. 


\section{Acknowledgments}

Nam Nguyen, Kevin Turner, Elliott Meckley, and Kent E. Hampton are gratefully acknowledged for their technical assistance. Custom glass and quartz ware was manufactured by

James R. Hodgson, Kansas State University. This material is based upon work supported by National Science Foundation Grant "From Crops to Commuting: Integrating the Social, Technological, and Agricultural Aspects of Renewable and Sustainable Biorefining (I-STAR)" NSF Award No.: DGE-0903701. Funding by the Center for Sustainable Energy, Kansas State University is gratefully acknowledged.

\section{References}

(1) Grätzel, M. Chemistry Letters 2005, 34, 8.

(2) Roeb, M.; Müller-Steinhagen, H. Science 2010, 329, 773.

(3) Smil, V. Nature 1999, 400, 415.

(4) Kirova-Yordanova, Z. Energy 2004, 29, 2373.

(5) Rafiqul, I.; Weber, C.; Lehmann, B.; Voss, A. Energy 2005, 30, 2487.

(6) Latscha, H. P.; Mutz, M. Chemie der Elemente, Chemie-Basiswissen IV, ISBN 978-3-64216914-4; Springer: Heidelberg, 2011.

(7) Hellman, A.; Baerends, E. J.; Biczysko, M.; Bligaard, T.; Christensen, C. H.; Clary, D. C.; Dahl, S.; van Harrevelt, R.; Honkala, K.; Jonsson, H.; Kroes, G. J.; Luppi, M.; Manthe, U.; Nørskov, J. K.; Olsen, R. A.; Rossmeisl, J.; Skúlason, E.; Tautermann, C. S.; Varandas, A. J. C.; Vincent, J. K. Journal of Physical Chemistry B 2006, 110, 17719.

(8) Christensen, C. H.; Johannessen, T.; Sørensen, R. Z.; Nørskov, J. K. Catalysis Today 2006, 111,140 . 
(9) Churchard, A. J.; Banach, E.; Borgschulte, A.; Caputo, R.; Chen, J.-C.; Clary, D. C.; Fijalkowski, K. J.; Geerlings, H.; Genova, R. V.; Grochala, W.; Jaroń, T.; Juanes-Marcos, J. C.; Kasemo, B.; Kroes, G.-J.; Ljubić, I.; Naujoks, N.; Nørskov, J. K.; Olsen, R. A.; Pendolino, F.; Remhof, A.; Románszki, L.; Tekin, A.; Vegge, T.; Zäch, M.; Züttel, A. Physical Chemistry Chemical Physics 2011, 13, 16955.

(10) Reiter, A. J.; Kong, S.-C. Energy \& Fuels 2008, 22, 2963.

(11) Reiter, A. J.; Kong, S. C. Fuel 2011, 90, 87.

(12) Skúlason, E.; Bligaard, T.; Gudmundsdóttir, S.; Studt, F.; Rossmeisl, J.; Abild-Pedersen, F.; Vegge, T.; Jónsson, H.; Nørskov, J. K. Physical Chemistry Chemical Physics 2012, 14,1235 .

(13) Valov, I.; Luerssen, B.; Mutoro, E.; Gregoratti, L.; De Souza, R. A.; Bredow, T.; Günther, S.; Barinov, A.; Dudin, P.; Martin, M.; Janek, J. Physical Chemistry Chemical Physics 2011, 13, 3394.

(14) Lee, D.-K.; Fischer, C. C.; Valov, I.; Reinacher, J.; Stork, A.; Lerch, M.; Janek, J. Physical Chemistry Chemical Physics 2011, 13, 1239.

(15) Amar, I. A.; Lan, R.; Petit, C. T. G.; Tao, S. Journal of Solid State Electrochemistry 2011, 15,1845 .

(16) Marnellos, G.; Stoukides, M. Science 1998, 282, 98.

(17) Knobloch, D. J.; Lobkovsky, E.; Chirik, P. J. Nature Chemistry 2010, 2, 30.

(18) Fryzuk, M. D. Accounts of Chemical Research 2009, 42, 127.

(19) Gilbertson, J. D.; Szymczak, N. K.; Tyler, D. R. Journal of the American Chemical Society 2005, 127, 10184.

(20) Rodriguez, M. M.; Bill, E.; Brennessel, W. W.; Holland, P. L. Science 2011, 334, 780. 
(21) Scheffe, J. R.; Li, J. H.; Weimer, A. W. International Journal of Hydrogen Energy 2010, $35,3333$.

(22) Chueh, W. C.; Falter, C.; Abbott, M.; Scipio, D.; Furler, P.; Haile, S. M.; Steinfeld, A. Science 2010, 330, 1797.

(23) Stamatiou, A.; Loutzenhiser, P. G.; Steinfeld, A. Energy \& Fuels 2010, 24, 2716.

(24) Miller, J. E.; Allendorf, M. D.; Diver, R. B.; Evans, L. R.; Siegel, N. P.; Stuecker, J. N. Journal of Materials Science 2008, 43, 4714.

(25) Licht, S.; Wang, B.; Wu, H. Journal of Physical Chemistry C 2011, 115, 11803.

(26) Gálvez, M. E.; Halmann, M.; Steinfeld, A. Industrial \& Engineering Chemistry Research 2007, 46, 2042.

(27) Michalsky, R.; Pfromm, P. H. Solar Energy 2011, 85, 2642.

(28) Michalsky, R.; Pfromm, P. H. AIChE Journal, DOI 10.1002/aic.13717 (in press).

(29) Michalsky, R.; Parman, B. J.; Amanor-Boadu, V.; Pfromm, P. H. Energy 2012, 42, 251.

(30) Barin, I.; Knacke, O. Thermochemical properties of inorganic substances; SpringerVerlag: Berlin Heidelberg New York, 1973.

(31) Warner, J. W.; Berry, R. S. Journal of Physical Chemistry 1987, 91, 2216.

(32) Shaffer, P. T. B. Plenum Press Handbooks of High-Temperature materials, No.1 Materials Index; Plenum Press: New York, 1964.

(33) Baba, H.; Katada, Y. Corrosion Science 2006, 48, 2510.

(34) Gálvez, M. E.; Frei, A.; Halmann, M.; Steinfeld, A. Industrial \& Engineering Chemistry Research 2007, 46, 2047.

(35) Fukumoto, S.; Hookabe, T.; Tsubakino, H. Journal of Materials Science 2000, 35, 2743.

(36) Heyns, A. M.; Prinsloo, L. C.; Range, K. J.; Stassen, M. Journal of Solid State Chemistry 1998, 137, 33 . 
(37) Weidman, M. C.; Esposito, D. V.; Hsu, Y. C.; Chen, J. G. Journal of Power Sources 2012, 202, 11 .

(38) Gregory, D. H. Journal of the Chemical Society-Dalton Transactions 1999, 259.

(39) Mowbray, D. J.; Martínez, J. I.; Calle-Vallejo, F.; Rossmeisl, J.; Thygesen, K. S.; Jacobsen, K. W.; Nørskov, J. K. Journal of Physical Chemistry C 2011, 115, 2244.

(40) Rossmeisl, J.; Nørskov, J. K.; Taylor, C. D.; Janik, M. J.; Neurock, M. Journal of Physical Chemistry B 2006, 110, 21833.

(41) Jacobsen, C. J. H.; Dahl, S.; Clausen, B. S.; Bahn, S.; Logadottir, A.; Nørskov, J. K. Journal of the American Chemical Society 2001, 123, 8404.

(42) Cairns, A. G.; Gallagher, J. G.; Hargreaves, J. S. J.; McKay, D.; Rico, J. L.; Wilson, K. Journal of Solid State Chemistry 2010, 183, 613.

(43) Chen, Y. H.; Kang, L.; Zhang, C. R.; Luo, Y. C.; Wu, Z. M.; Zhang, M. L. Chinese Journal of Inorganic Chemistry 2008, 24, 1029.

(44) Sharma, H.; Garg, I.; Dharamvir, K.; Jindal, V. K. Journal of Computational and Theoretical Nanoscience 2010, 7, 2297.

(45) Bai, Q.; Song, B.; Hou, J.; He, P. Physics Letters A 2008, 372, 4545.

(46) Chen, Y.-H.; Kang, L.; Zhang, C.-R.; Luo, Y.-C.; Yuan, L.-H.; Li, Y.-L. Acta Physica Sinica 2008, 57, 6265.

(47) Chaudhari, A.; Lee, S.-L. International Journal of Quantum Chemistry 2007, 107, 212.

(48) Blomberg, M. R. A.; Siegbahn, P. E. M. Theoretica Chimica Acta 1992, 81, 365.

(49) Mola, E. E.; Coronel, E.; Joly, Y.; Vicente, J. L. Langmuir 1988, 4, 917.

(50) Nagakura, S.; Ötsuka, N. Journal of the Physical Society of Japan 1975, 39, 1047.

(51) Li, Z.; Wang, P.; Chen, H.; Cheng, X. Physica B-Condensed Matter 2011, 406, 1182.

(52) Chen, H.; Lei, X. L.; Liu, L. R.; Liu, Z. F.; Zhu, H. J. Chinese Physics B 2010, 19. 
(53) Qi, J.; Jiang, L. H.; Jiang, Q. A.; Wang, S. L.; Sun, G. Q. Journal of Physical Chemistry C 2010, 114, 18159.

(54) Levenspiel, O. Chemical reaction engineering, Third Edition, Chapter 25 Fluid-particle reactions: Kinetics; John Wiley \& Sons: New York, 1999.

(55) Ettmayer, P. Monatshefte für Chemie 1970, 101, 127.

(56) Gillot, B.; El Guendouzi, M.; Laarj, M. Materials Chemistry and Physics 2001, 70, 54.

(57) Öijerholm, J. Division of Corrosion Science, Department of Chemistry, School of Chemical Science and Engineering, Royal Institute of Technology, Stockholm, 2007.

(58) Christiansen, T. L.; Somers, M. A. J. International Journal of Materials Research 2008, 99, 999.

(59) Chueh, W. C.; Haile, S. M. Philosophical Transactions of the Royal Society aMathematical Physical and Engineering Sciences 2010, 368, 3269. 


\section{Tables}

Table 1. Characterization of the metal nitride powder beds

\begin{tabular}{|c|c|c|c|c|c|c|c|}
\hline nitride & $\mathrm{Mg}_{3} \mathrm{~N}_{2}$ & w-AIN & $\begin{array}{l}\alpha-\mathrm{Ca}_{3} \mathrm{~N}_{2} \\
\left(\mathrm{Ca}_{2} \mathrm{~N}\right)\end{array}$ & $\begin{array}{l}\mathrm{Cr}_{2} \mathrm{~N} \\
(\mathrm{CrN})\end{array}$ & $\begin{array}{l}\mathrm{Mn}_{4} \mathrm{~N} \\
\left(\mathrm{Mn}_{6} \mathrm{~N}_{2.58}\right)\end{array}$ & $\mathrm{Zn}_{3} \mathrm{~N}_{2}$ & $\mathrm{~B}-\mathrm{Mo}_{2} \mathrm{~N}$ \\
\hline space group & la-3 & $P 6_{3} m c$ & $\begin{array}{l}\text { la-3 } \\
(R-3 m)\end{array}$ & $\begin{array}{l}P-31 m \\
(F m-3 m)\end{array}$ & $\begin{array}{l}P m-3 m \\
\left(P 6_{3} 22\right)\end{array}$ & la-3 & $14_{1} /$ amd \\
\hline$x_{\text {nitride }}{ }^{a}(w t \%)$ & $100 \pm 1$ & $100 \pm 1$ & $\begin{array}{l}86 \pm 5 \\
(14 \pm 5)\end{array}$ & $\begin{array}{l}85 \pm 1 \\
(10.1 \pm 0.3)\end{array}$ & $\begin{array}{l}70 \pm 5 \\
(28 \pm 3)\end{array}$ & $100 \pm 1$ & $24.9 \pm 0.4$ \\
\hline$<d_{\text {nitride }}>b(\mu \mathrm{m})$ & $27 \pm 11$ & $16 \pm 6$ & $105 \pm 25$ & $43 \pm 14$ & $46 \pm 19$ & $21 \pm 7$ & $13 \pm 6$ \\
\hline$A_{B E T^{c}}^{c}\left(\mathrm{~m}^{2} \mathrm{~g}^{-1}\right)$ & $8.8 \pm 0.3$ & $4.9 \pm 0.1$ & $0.67 \pm 0.01$ & $0.40 \pm 0.01$ & $0.27 \pm 0.01$ & $3.75 \pm 0.03$ & $0.43 \pm 0.01$ \\
\hline$A_{b e d}^{d}\left(\mathrm{~cm}^{2}\right)$ & 42 & 42 & 42 & 33 & 33 & 42 & 33 \\
\hline$\Phi e\left(m^{3} m^{-3}\right)$ & 0.68 & 0.69 & 0.55 & 0.55 & 0.65 & 0.73 & 0.73 \\
\hline
\end{tabular}

$a$, nitride weight fraction; $b$, average particle diameter; $c$, BET surface area; $d$, powder bed surface \pm $5.24 \%$ (via error propagation), powder bed thickness generally $<1 \mathrm{~mm} ; e$, void space fraction \pm $5.15 \%$ (via error propagation) 
Table 2. Partial nitrogen charge of binary metal nitrides

\begin{tabular}{|c|c|c|}
\hline nitride & $q_{N}{ }^{a}$ & methods \\
\hline $\mathrm{Mg}_{3} \mathrm{~N}_{2}$ & $-2.06 \pm 0.19$ & MPA 43 \\
\hline W-AIN & $-0.36 \pm 0.05$ & MPA 44,45 \\
\hline $\mathrm{a}-\mathrm{Ca}_{3} \mathrm{~N}_{2}\left(\mathrm{Ca}_{2} \mathrm{~N}\right)$ & $-1.91 \pm 0.29$ & MPA for $\mathrm{Ca}_{3} \mathrm{~N}_{2} 46$ \\
\hline $\mathrm{Cr}_{2} \mathrm{~N}(\mathrm{CrN})$ & $-0.30 \pm 0.03$ & MPA for CrN ${ }^{47}, \mathrm{CASSCF}$ for $\mathrm{CrN}{ }^{48}, \mathrm{MNDO}^{b}$ for $\mathrm{Cr}_{2} \mathrm{~N}{ }^{49}$ \\
\hline $\mathrm{Mn}_{4} \mathrm{~N}\left(\mathrm{Mn}_{6} \mathrm{~N}_{258}\right)$ & $-0.47 \pm 0.18$ & electron diffraction for $\mathrm{Mn}_{4} \mathrm{~N}{ }^{50}, \mathrm{MPA}$ for $\mathrm{MnN} 47$ \\
\hline $\mathrm{Zn}_{3} \mathrm{~N}_{2}$ & -0.64 & MPA 51 \\
\hline $\mathrm{B}-\mathrm{Mo}_{2} \mathrm{~N}$ & $-0.53 \pm 0.10$ & MPA for $\mathrm{Mo}_{2 \mathrm{n}} \mathrm{N}_{\mathrm{n}}$ clusters with $\mathrm{n} \geq 4{ }^{52}$, MPA 53 \\
\hline
\end{tabular}

$a$, The partial nitrogen charge $q_{N}$ (in units of the elementary charge e) is given as arithmetic average with one standard deviation of up to 12 literature values; $b$, neglecting a relative high value for $\mathrm{CrN}$; MPA, Mulliken population analysis; CASSCF, completeactive-space self-consistent-field; MNDO, modified neglect of diatomic overlap. 
Table 3. Kinetic data and modeling ${ }^{a}$

\begin{tabular}{|c|c|c|c|c|c|c|}
\hline \multicolumn{7}{|c|}{ ionic nitrides } \\
\hline $\begin{array}{l}\text { met } \\
\text { as nit }\end{array}$ & $\begin{array}{l}\text { al } T_{\text {hyd }} \\
\text { ide }\left({ }^{\circ} \mathrm{C}\right)\end{array}$ & $\begin{array}{c}r_{0}\left(\mathrm{~mol}_{\mathrm{NH} 3}\right. \\
\left.\mathrm{mol}_{\text {metal }}^{-1} \mathrm{~s}^{-1}\right)\end{array}$ & model & $\begin{array}{c}k \\
\left(\mathrm{~s}^{-1}\right)\end{array}$ & $\begin{array}{l}R^{2} \\
>\end{array}$ & $\begin{array}{l}\Delta t_{\text {fit }} \\
\text { (min) }\end{array}$ \\
\hline $\mathrm{Mg}$ & $\begin{array}{l}200 \\
300 \\
500\end{array}$ & $\begin{array}{l}1.0 \pm 0.2 \times 10^{-4} \\
2.3 \pm 0.4 \times 10^{-5} \\
1.1 \pm 0.2 \times 10^{-3}\end{array}$ & $\begin{array}{l}g \\
g \\
g^{b}\end{array}$ & $\begin{array}{l}6.2 \times 10^{-4} \\
9.7 \times 10^{-5} \\
1.2 \times 10^{-3}\end{array}$ & $\begin{array}{l}0.80 \\
0.99 \\
0.90\end{array}$ & $\begin{array}{l}10 \\
60 \\
10\end{array}$ \\
\hline $\mathrm{Ca}$ & $\begin{array}{l}200 \\
300 \\
500\end{array}$ & $\begin{array}{l}1.4 \pm 0.2 \times 10^{-5} \\
4.3 \pm 0.6 \times 10^{-6} \\
1.6 \pm 0.2 \times 10^{-5}\end{array}$ & $\begin{array}{l}g^{b} \\
g^{b} \\
g^{b}\end{array}$ & $\begin{array}{l}7.7 \times 10^{-5} \\
4.4 \times 10^{-5} \\
2.9 \times 10^{-4}\end{array}$ & $\begin{array}{l}0.99 \\
0.90 \\
0.75\end{array}$ & $\begin{array}{l}60 \\
60 \\
60\end{array}$ \\
\hline $\mathrm{Zn}$ & $\begin{array}{r}300 \\
500 \\
1000\end{array}$ & $\begin{array}{l}8 \pm 1 \times 10^{-7} \\
3.3 \pm 0.6 \times 10^{-4} \\
2.9 \pm 0.4 \times 10^{-4}\end{array}$ & $\begin{array}{l}\mathrm{s} \\
\mathrm{g} \\
\mathrm{s}\end{array}$ & $\begin{array}{l}3.3 \times 10^{-10} \\
8.9 \times 10^{-4} \\
2.8 \times 10^{-5}\end{array}$ & $\begin{array}{l}0.87 \\
0.91 \\
0.72\end{array}$ & $\begin{array}{r}10 \\
10 \\
5\end{array}$ \\
\hline \multicolumn{7}{|c|}{ covalent nitrides } \\
\hline $\mathrm{Al}$ & $\begin{array}{r}300 \\
500 \\
1000\end{array}$ & $\begin{array}{l}9 \pm 2 \times 10^{-8} \\
8 \pm 1 \times 10^{-6} \\
4.9 \pm 0.8 \times 10^{-5}\end{array}$ & $\begin{array}{l}\mathrm{s} \\
\mathrm{s} \\
\mathrm{s}\end{array}$ & $\begin{array}{l}6.3 \times 10^{-13} \\
6.9 \times 10^{-9} \\
1.4 \times 10^{-7}\end{array}$ & $\begin{array}{l}0.96 \\
0.92 \\
0.88\end{array}$ & $\begin{array}{l}10 \\
60 \\
60\end{array}$ \\
\hline \multicolumn{7}{|c|}{ interstitial and intermediate nitrides } \\
\hline $\mathrm{Cr}$ & $\begin{array}{r}500 \\
600 \\
1000\end{array}$ & $\begin{array}{l}1.5 \pm 0.3 \times 10^{-7} \\
1.0 \pm 0.2 \times 10^{-7} \\
1.8 \pm 0.3 \times 10^{-6}\end{array}$ & $\begin{array}{l}\mathrm{s} \\
\mathrm{s} \\
\mathrm{s}\end{array}$ & $\begin{array}{l}7.6 \times 10^{-12} \\
3.3 \times 10^{-12} \\
1.2 \times 10^{-9}\end{array}$ & $\begin{array}{l}0.80 \\
0.95 \\
0.99\end{array}$ & $\begin{array}{l}30 \\
10 \\
30\end{array}$ \\
\hline $\mathrm{Mn}$ & $\begin{array}{r}300 \\
500 \\
1000\end{array}$ & $\begin{array}{l}8 \pm 1 \times 10^{-8} \\
9.7 \pm 0.9 \times 10^{-6} \\
5.3 \pm 0.7 \times 10^{-6}\end{array}$ & $\begin{array}{l}\mathrm{r}^{b} \\
\mathrm{~s} \\
\mathrm{~s}\end{array}$ & $\begin{array}{l}8.2 \times 10^{-8} \\
6.9 \times 10^{-8} \\
3.6 \times 10^{-8}\end{array}$ & $\begin{array}{l}0.98 \\
0.93 \\
0.96\end{array}$ & $\begin{array}{l}30 \\
60 \\
30\end{array}$ \\
\hline Mo & $\begin{array}{r}500 \\
600 \\
1000\end{array}$ & $\begin{array}{l}3.2 \pm 0.3 \times 10^{-5} \\
4.9 \pm 0.7 \times 10^{-6} \\
7 \pm 1 \times 10^{-6}\end{array}$ & $\begin{array}{l}\mathrm{s} \\
\mathrm{s} \\
\mathrm{s}\end{array}$ & $\begin{array}{l}6.4 \times 10^{-6} \\
1.5 \times 10^{-7} \\
4.0 \times 10^{-7}\end{array}$ & $\begin{array}{l}0.82 \\
0.88 \\
0.85\end{array}$ & $\begin{array}{l}30 \\
30 \\
30\end{array}$ \\
\hline
\end{tabular}

a, Applying shrinking core models (controlled by: $s$, diffusion through the solid reaction product; $r$, reaction; $g$, diffusion through the gas film) in the time range $\Delta t_{\text {fit }}, b, r$ or $g$ respectively show an only slightly $(<0.05)$ lower $R^{2}$ value. 


\section{Schemes and Charts}

Scheme 1. Two-step reactive $\mathrm{NH}_{3}$ synthesis from

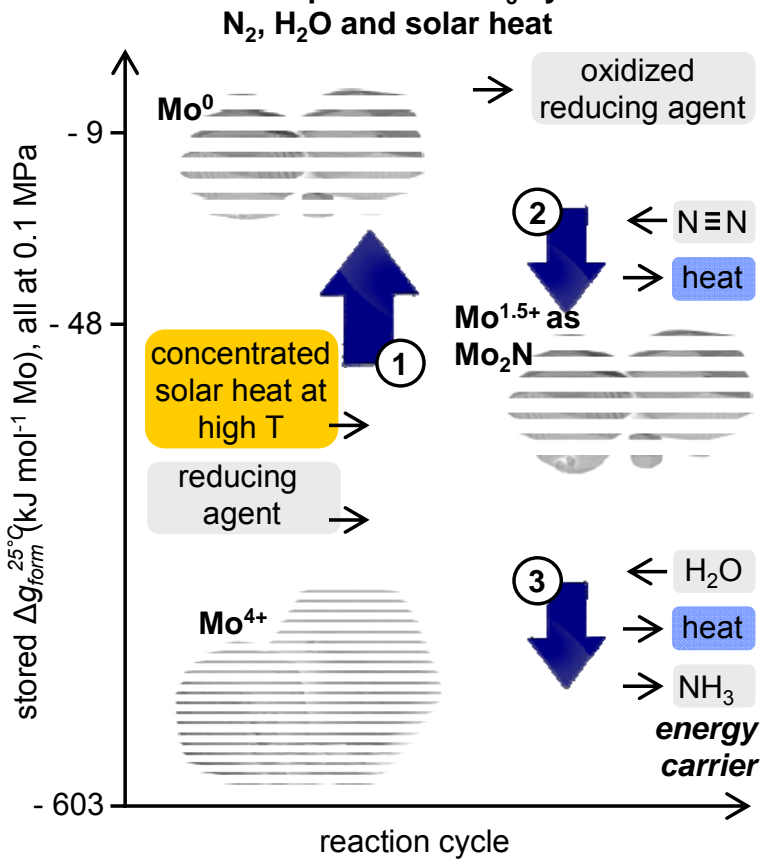

The endothermic reduction (1) of an oxidized material (e.g., $\mathrm{Mo}^{4+}$ ) and the exothermic reduction of $\mathrm{N}_{2}(2)$ may be conducted in one step. This generates nominally $\mathrm{N}^{3-}$ that can be protonated with $\mathrm{H}_{2} \mathrm{O}(3)$. 


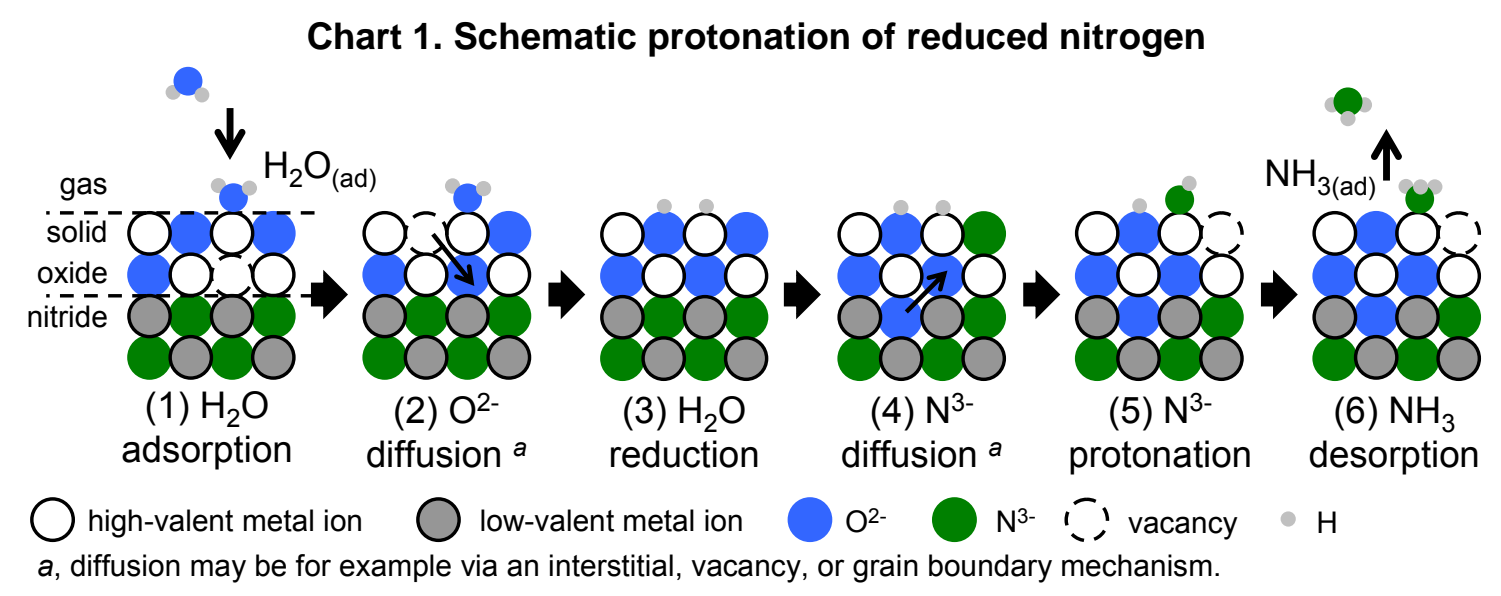




\section{Figure captions}

Figure 1: Rationale for the choice of metals: (A) Enthalpy ${ }^{30}$ mapping of the exothermic heat liberated during the $\mathrm{N}^{3-}$ oxidation $\left(\Delta h_{N 3-}\right.$ ox., Eq.3) versus $\mathrm{N}_{2}$ reduction $\left(\Delta h_{N 2}\right.$ red., Eq.2), both relative to the energy supplied during the solar-thermal metal oxide reduction step (Eq.1). Empty circles mark materials that do not fix $0.1 \mathrm{MPa} \mathrm{N}$, do not liberate $\mathrm{NH}_{3}$ effectively, or are radioactive (see online materials). (B) Correlation of $\Delta h_{N 3-}$ ox. with the free energy ${ }^{30}$ of the reaction $\left(\Delta g_{N 3-o x .}\right)$. All computations are at $25^{\circ} \mathrm{C}$ and $0.1 \mathrm{MPa}$.

Figure 2: Correlation between the bulk heat of formation ${ }^{30}$ for transition metal nitrides, $g_{f}$, in $\mathrm{kJ}$ $\mathrm{mol}^{-1}$ lattice nitrogen versus the number of d electrons, $N_{d}$. A nearly quantitative linear correlation (solid line) is obtained when excluding elements with nominally only one d electron or with a completely occupied $3 \mathrm{~d}^{10}$ orbital (empty circles, dashed line).

Figure 3: Experimental setups ( $a, \mathrm{~N}_{2}$ gas; $b, \mathrm{H}_{2}$ gas, $c$, flow meter; $d$, gas mixing; $e$, tubular flowthrough furnace; $f$, metal powder in quartz boat; $g$, heating plate; $h$, liquid level control; $i$, liquid $\mathrm{H}_{2} \mathrm{O} ; j$, metal nitride powder in quartz boat; $k$, magnetic stirrer; $l, 10 \mathrm{mM} \mathrm{HCl}$ chilled with icecold $\mathrm{H}_{2} \mathrm{O} ; m, \mathrm{NH}_{3}$ gas detection tube).

Figure 4: Representative results (see online materials) for steam hydrolysis of metal nitride powders illustrating the kinetic fitting with maximized $R^{2}$ (see Table 3): (A) solid-state diffusiongoverned $\mathrm{NH}_{3}$ formation from $\mathrm{Al}$ (circle), $\mathrm{Cr}$ (diamond), Mn (triangle), and Mo (square) nitrides and (B) the supply of $\mathrm{H}_{2} \mathrm{O}$ from the gas phase controlling $\mathrm{NH}_{3}$ formation from $\mathrm{Mg}$ (circle), $\mathrm{Ca}$ (diamond) and $\mathrm{Zn}$ (triangle, at $500^{\circ} \mathrm{C}$, see Table 3) nitrides. Error bars are via error propagation. 
Figure 5: The specific rate constant $k$ (maximum $R^{2}$, Table 3) versus the specific volume change $\left(\Delta v_{h y d}\right)$ when oxidizing the nitrides at $300^{\circ} \mathrm{C}\left(\rho_{i}\right.$ is the density in mol $\mathrm{m}^{-3}$ of substance i). Error bars are three standard deviations; $R^{2}$ for the fit (line) is $>0.91$. SEM images are representative nitrides of $(a)$ or $(b) \mathrm{Mn}$, and $(c)$ or $(d)$ Ca before or after the hydrolysis respectively.

Figure 6: The specific rate constant $k_{s}$ at $300^{\circ} \mathrm{C}$ (circles, solid line fit with $R^{2}>0.99$ ) or $500^{\circ} \mathrm{C}$ (diamonds, fit excluding $\mathrm{Zn}^{2+}$ with $R^{2}>0.76$ ) versus nitride ionicity (arrow see Section 4.4). Metal cations indicated mark the oxides/hydroxides detected after hydrolysis. Error propagation using three standard deviations yields in average ca. $\pm 2.22 \%\left(300^{\circ} \mathrm{C}\right)$ or $\pm 3.23 \%\left(500^{\circ} \mathrm{C}\right)$.

Figure 7: The diffusion coefficient $D$ for steam hydrolysis at $500^{\circ} \mathrm{C}$ plotted against (A) the nominal radius of a single metal ion with $R^{2}>0.28$ or (B) the nitride ionicity with $R^{2}>0.97$. The inlet shows the characteristic time for the diffusion process with $R^{2}>0.96 . R^{2}$ computations are based on the data set without $\mathrm{Mg}^{2+}$ and $\mathrm{Ca}^{2+}$. Error bars on the ordinate are via error propagation. 


\section{Figures}
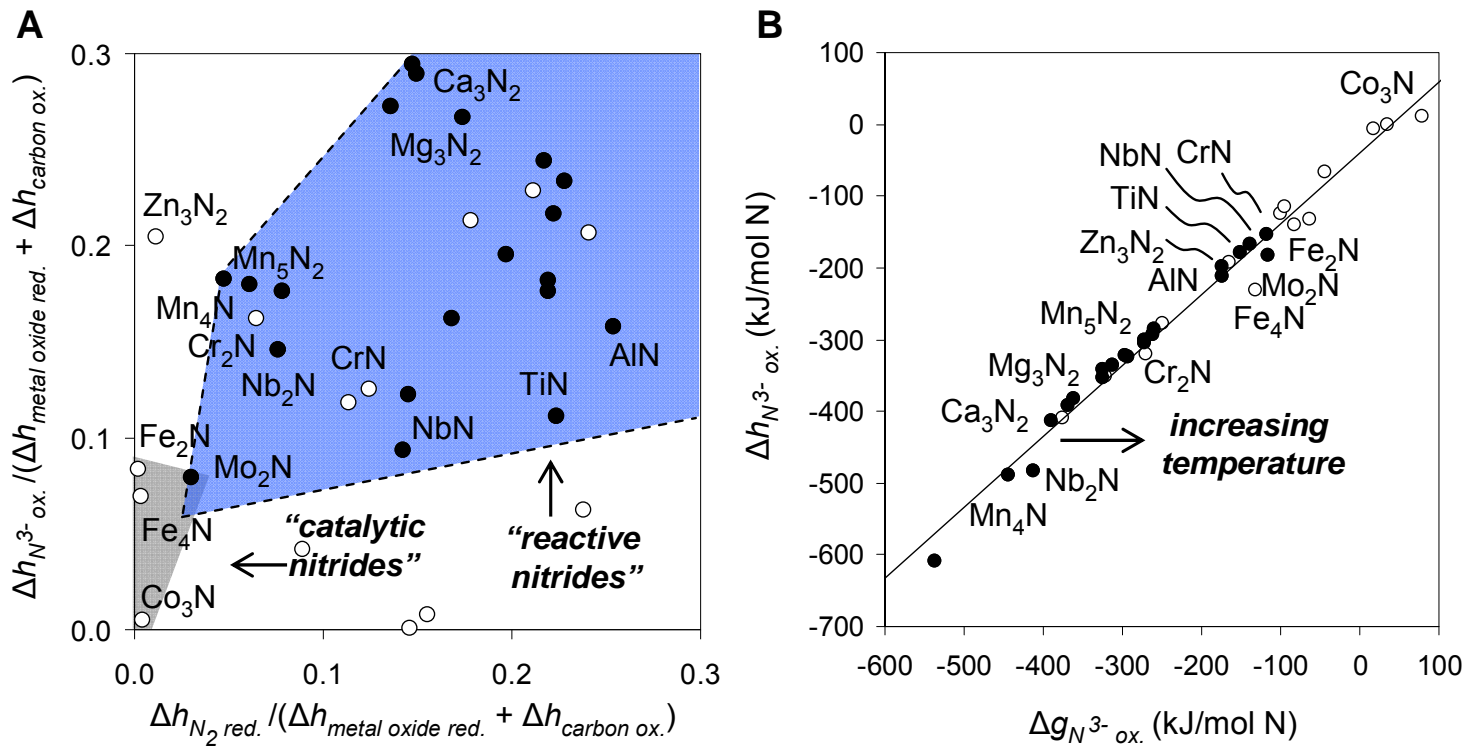

Figure 1: Rationale for the choice of metals: (A) Enthalpy ${ }^{30}$ mapping of the exothermic heat liberated during the $\mathrm{N}^{3-}$ oxidation $\left(\Delta h_{N 3-}\right.$ ox., Eq.3) versus $\mathrm{N}_{2}$ reduction $\left(\Delta h_{N 2}\right.$ red., Eq.2), both relative to the energy supplied during the solar-thermal metal oxide reduction step (Eq.1). Empty circles mark materials that do not fix $0.1 \mathrm{MPa} \mathrm{N}_{2}$, do not liberate $\mathrm{NH}_{3}$ effectively, or are radioactive (see online materials). (B) Correlation of $\Delta h_{N 3-}$ ox. with the free energy ${ }^{30}$ of the reaction $\left(\Delta g_{N 3-\text { ox. }}\right)$. All computations are at $25^{\circ} \mathrm{C}$ and $0.1 \mathrm{MPa}$. 


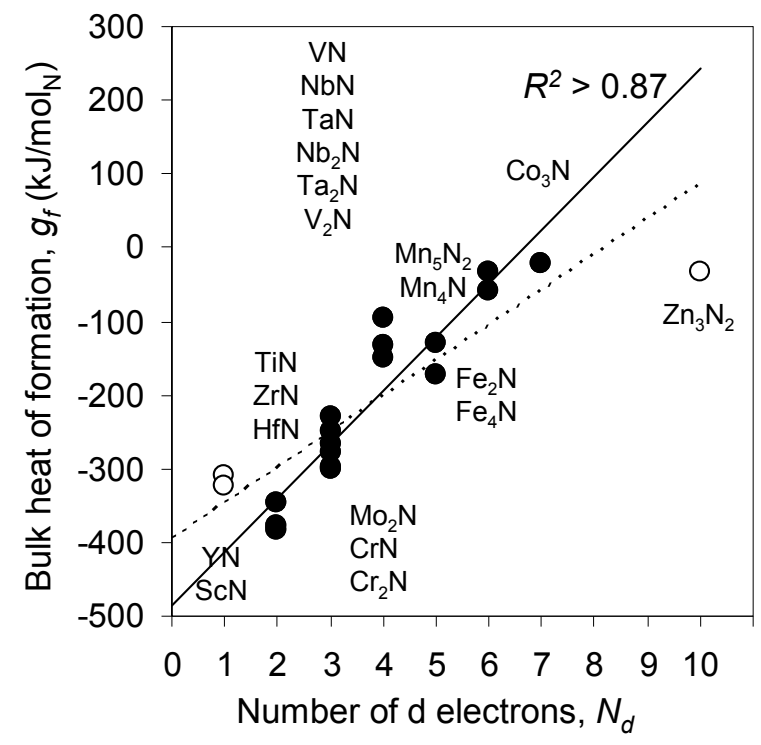

Figure 2: Correlation between the bulk heat of formation ${ }^{30}$ for transition metal nitrides, $g_{f}$, in $\mathrm{kJ}$ $\mathrm{mol}^{-1}$ lattice nitrogen versus the number of $\mathrm{d}$ electrons, $N_{d}$. A nearly quantitative linear correlation (solid line) is obtained when excluding elements with nominally only one d electron or with a completely occupied $3 \mathrm{~d}^{10}$ orbital (empty circles, dashed line). 


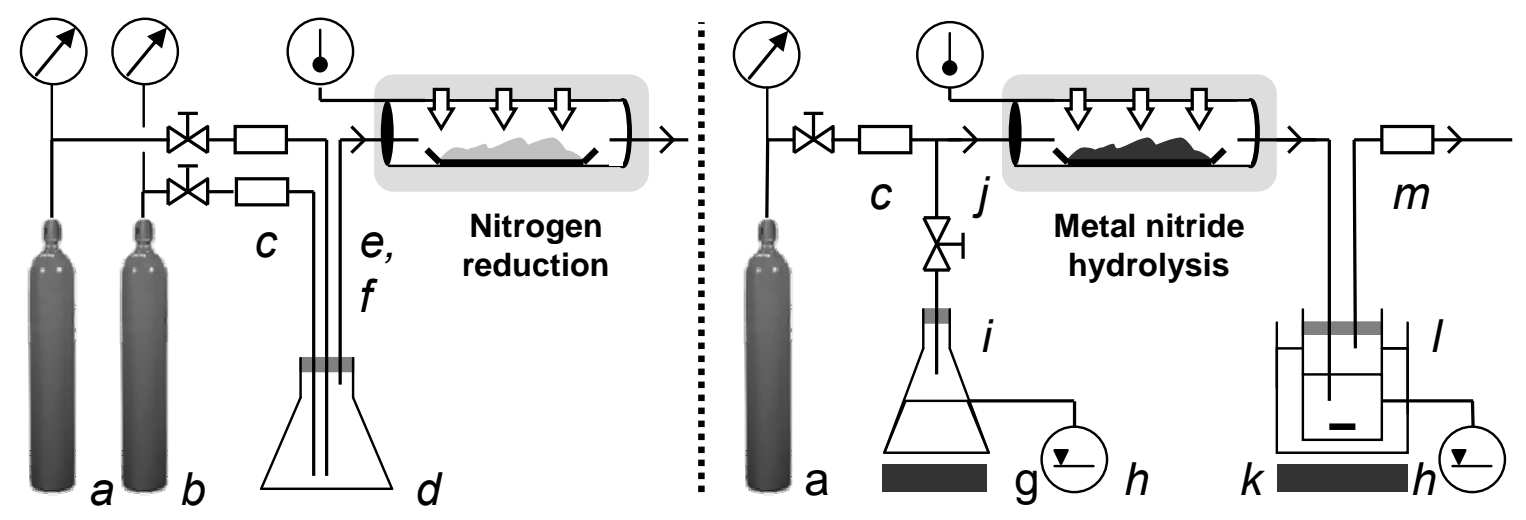

Figure 3: Experimental setups ( $a, \mathrm{~N}_{2}$ gas; $b, \mathrm{H}_{2}$ gas, $c$, flow meter; $d$, gas mixing; $e$, tubular flowthrough furnace; $f$, metal powder in quartz boat; $g$, heating plate; $h$, liquid level control; $i$, liquid $\mathrm{H}_{2} \mathrm{O} ; j$, metal nitride powder in quartz boat; $k$, magnetic stirrer; $l, 10 \mathrm{mM} \mathrm{HCl}$ chilled with icecold $\mathrm{H}_{2} \mathrm{O} ; m, \mathrm{NH}_{3}$ gas detection tube). 

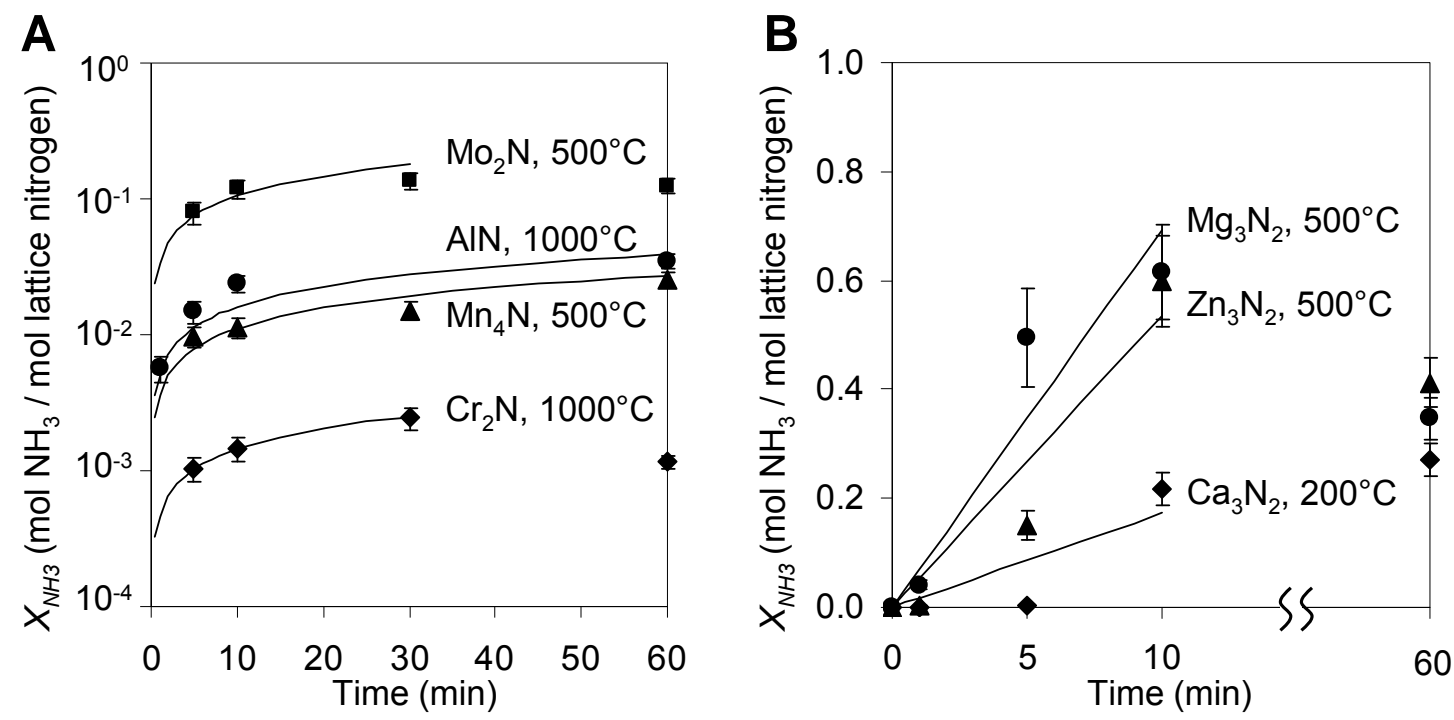

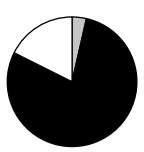

AIN

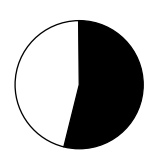

$\mathrm{Cr}_{2} \mathrm{~N}$

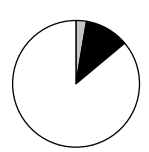

$\mathrm{Mn}_{4} \mathrm{~N}$

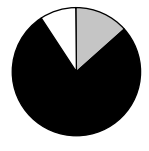

$\mathrm{Mo}_{2} \mathrm{~N}$

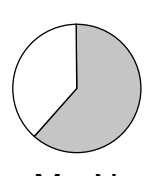

$\mathrm{Mg}_{3} \mathrm{~N}_{2}$

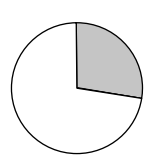

$\mathrm{Ca}_{3} \mathrm{~N}_{2}$

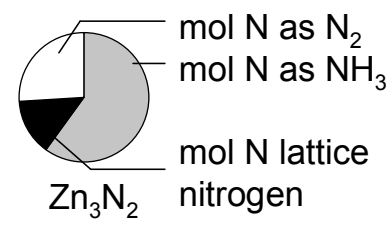

Figure 4: Representative results (see online materials) for steam hydrolysis of metal nitride powders illustrating the kinetic fitting with maximized $R^{2}$ (see Table 3): (A) solid-state diffusiongoverned $\mathrm{NH}_{3}$ formation from $\mathrm{Al}$ (circle), $\mathrm{Cr}$ (diamond), Mn (triangle), and Mo (square) nitrides and (B) the supply of $\mathrm{H}_{2} \mathrm{O}$ from the gas phase controlling $\mathrm{NH}_{3}$ formation from $\mathrm{Mg}$ (circle), $\mathrm{Ca}$ (diamond) and $\mathrm{Zn}$ (triangle, at $500^{\circ} \mathrm{C}$, see Table 3) nitrides. Error bars are via error propagation. 


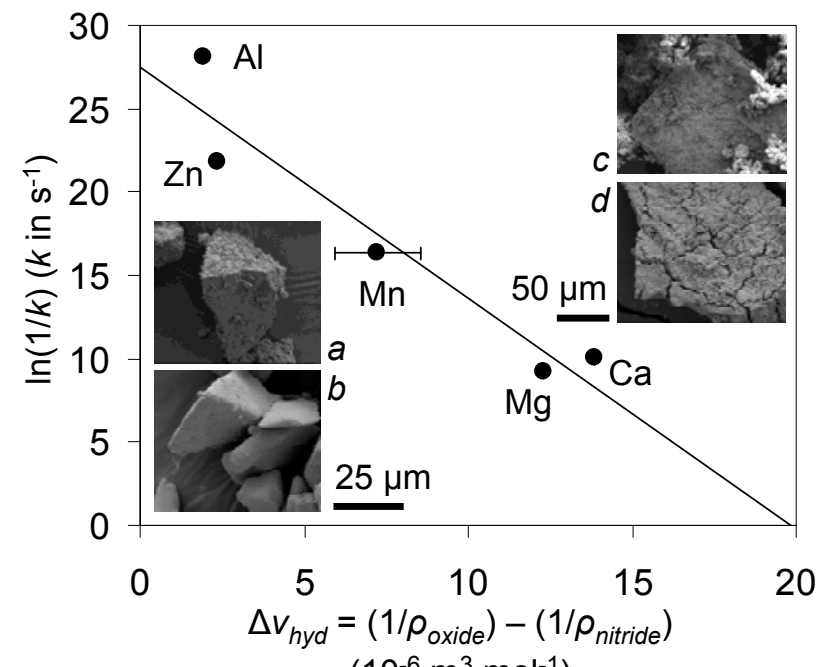

$\left(10^{-6} \mathrm{~m}^{3} \mathrm{~mol}^{-1}\right)$

Figure 5: The specific rate constant $k$ (maximum $R^{2}$, Table 3 ) versus the specific volume change $\left(\Delta v_{\text {hyd }}\right)$ when oxidizing the nitrides at $300^{\circ} \mathrm{C}\left(\rho_{i}\right.$ is the density in $\mathrm{mol} \mathrm{m} \mathrm{m}^{-3}$ of substance i). Error bars are three standard deviations; $R^{2}$ for the fit (line) is $>0.91$. SEM images are representative nitrides of $(a)$ or $(b) \mathrm{Mn}$, and $(c)$ or $(d)$ Ca before or after the hydrolysis respectively. 


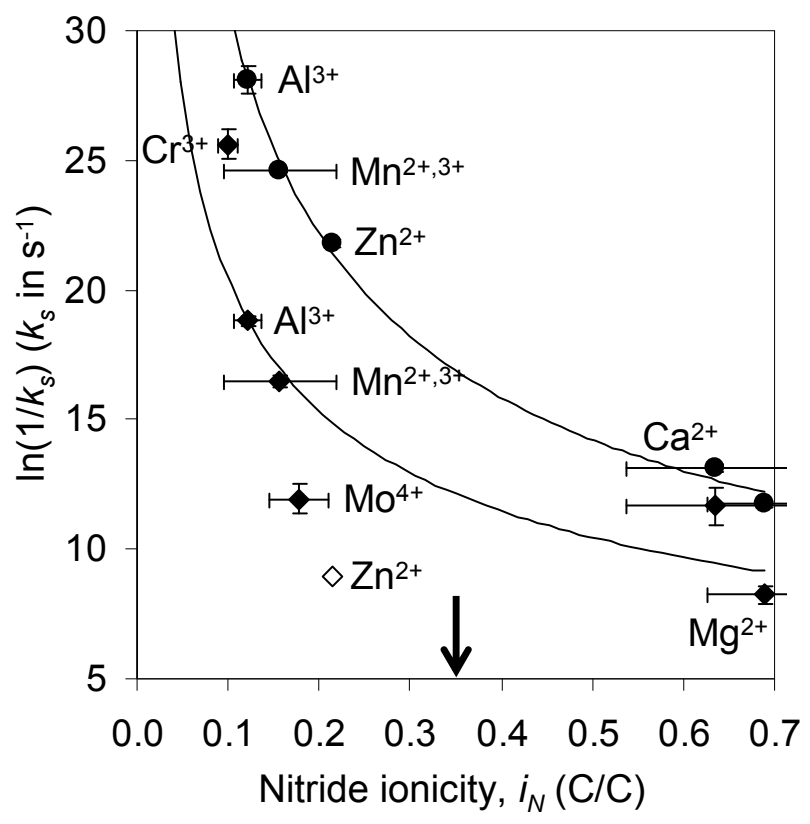

Figure 6: The specific rate constant $k_{s}$ at $300^{\circ} \mathrm{C}$ (circles, solid line fit with $R^{2}>0.99$ ) or $500^{\circ} \mathrm{C}$ (diamonds, fit excluding $\mathrm{Zn}^{2+}$ with $R^{2}>0.76$ ) versus nitride ionicity (arrow see Section 4.4). Metal cations indicated mark the oxides/hydroxides detected after hydrolysis. Error propagation using three standard deviations yields in average ca. $\pm 2.22 \%\left(300^{\circ} \mathrm{C}\right)$ or $\pm 3.23 \%\left(500^{\circ} \mathrm{C}\right)$. 

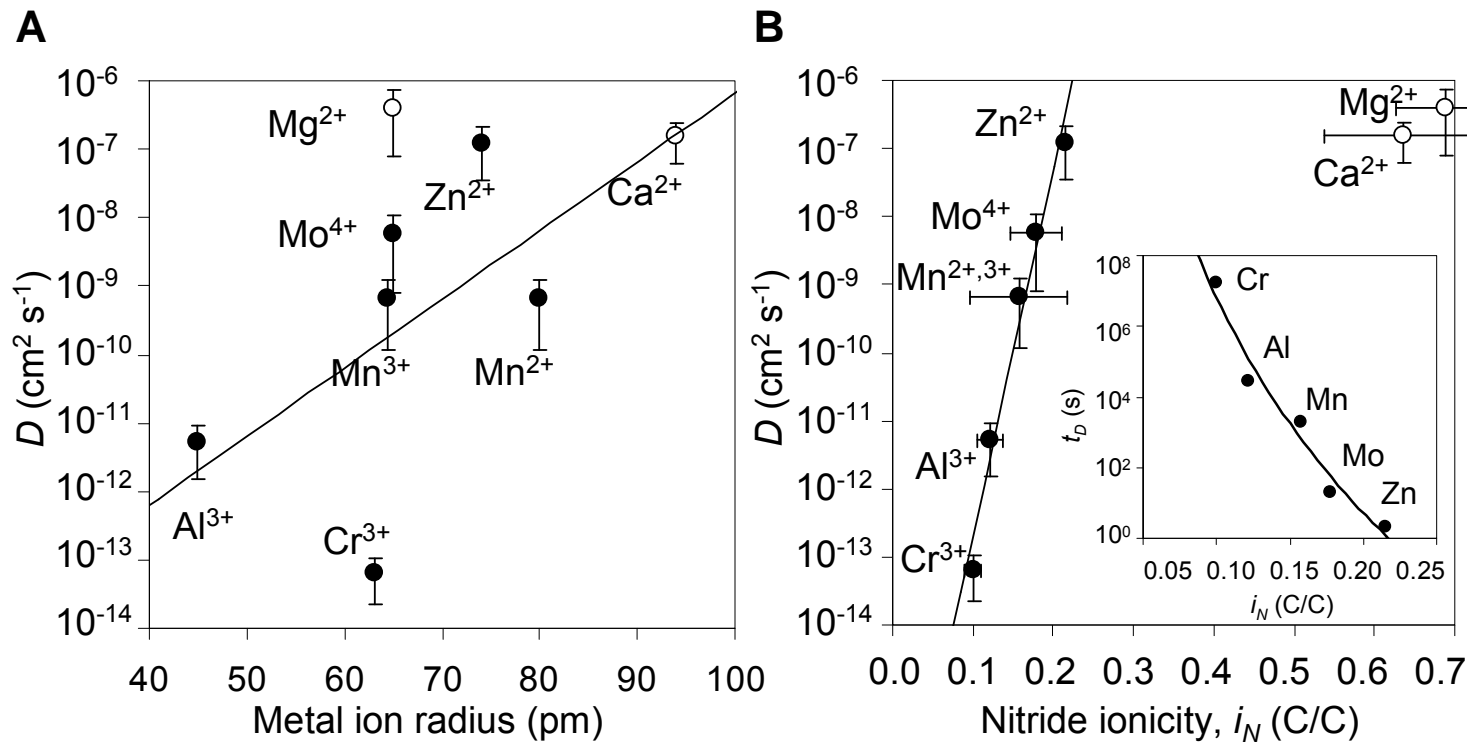

Figure 7: The diffusion coefficient $D$ for steam hydrolysis at $500^{\circ} \mathrm{C}$ plotted against (A) the nominal radius of a single metal ion with $R^{2}>0.28$ or (B) the nitride ionicity with $R^{2}>0.97$. The inlet shows the characteristic time for the diffusion process with $R^{2}>0.96 . R^{2}$ computations are based on the data set without $\mathrm{Mg}^{2+}$ and $\mathrm{Ca}^{2+}$. Error bars on the ordinate are via error propagation. 


\section{Online Table of Content Image}

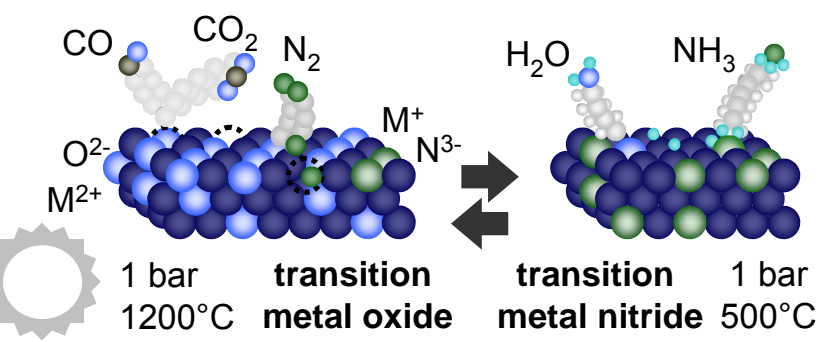

